\title{
WEBSITE FEATURES THAT GAVE RISE TO SOCIAL COMMERCE: \\ A HISTORICAL ANALYSIS
}

\author{
Renata Curty and Ping Zhang \\ School of Information Studies, Syracuse University \\ Syracuse, NY 13244 \\ rcurty@syr.edu, pzhang@syr.edu \\ Pre-publication version \\ Last revised: April 14, 2013
}

Citation: Curty, Renata and Ping Zhang (Forthcoming 2013), Website Features that Gave Rise to Social Commerce: A Historical Analysis, Electronic Commerce Research and Applications (ECRA), Vol. 12

\begin{abstract}
Social commerce is a form of commerce mediated by social media and social networking services (SNS)As a multifaceted phenomenon, social commerce can be studied from different angles and analyzed through the lens of various disciplines. This article examines website technical features to depict the transformation of e-commerce into social commerce. We first develop a conceptual framework to capture three emphases of e-commerce: transactional, relational and social. Then, we use the framework to conduct an historical analysis of the actual website screen captures for five top e-commerce companies since their websites were established. We were able to identify and classify a total of 174 emerging technical features. Our results show that: (1) all three emphases were expressed in the websites and have been reshaping their business and marketing strategies over the years; (2) there was a clear blooming of social features in 2007; and (3) there has been a significant effort to strengthen customer and merchant ties through relational features. Our findings signal that there still is room for further exploration of the social emphasis.
\end{abstract}

Keywords: E-commerce, framework development, historical analysis, social commerce, social shopping, survey research, Wayback Machine. 


\section{INTRODUCTION}

Social commerce is a new wave of e-commerce in which traditional e-commerce is mediated by social media and social networking services in order to promote online transactions and shopping-related information exchanges (Wang and Zhang 2012). Social commerce utilizes features that support people’s participation in the marketing, selling, comparing, curating, buying, and sharing of products and services in online and offline marketplaces and communities (Zhou et al., 2013). The increasing attention and popularity gained by social media and social networking services over the past several years have brought new opportunities for e-commerce. They also have challenged and redefined traditional vendor-push business models and marketing strategies (Liang and Turban 2011). Social commerce is a more social, innovative and collaborative way of doing business (Parise and Guinan 2008). It has transformed e-commerce into a more socially-centered and user-driven environment (Wigand et al. 2008). More than ever before, consumers are at the center of social commerce business models (Huang and Benyoucef 2013). At the same time, e-commerce businesses have been exploring new features to add to their technology platforms, and designing more tailored websites (Hajli 2012). Web 2.0 technologies and tools are being applied to engage people to share interests, with or without real-life connections in commerce related activities. In this sense, weblogs, wikis, and social bookmarking systems are changing the role of consumers into more participatory actors in the commercial process (Ickler et al. 2009).

Despite the pervasiveness of social commerce in business and in people's lives, not enough scholarly attention has been devoted to study the social commerce phenomenon (Wang and Zhang 2012). Among the published academic studies on social commerce, some have focused on consumer behavior and social shopping activities by observing factors such as loyalty (Huang 2011), social influence (Amblee and Bui 2011, Kim and Srivastava 2007, Pagani and Mirabello 2011), social ties (Liang et al. 2011) and purchasing behavior predictors (Olbrich and Holsing 2011). Some examined design features and their impacts. For example, taking a more artifact-oriented approach, Grange and Benbasat (2010) analyzed both utilitarian and hedonic affordances of social shopping features and the perceived usefulness and enjoyment 
associated with them. Huang and Benyoucef (2013) proposed a multi-layered model containing a set of principles for the design of social commerce websites, which is divided into four major layers: individual, conversation, community and commerce. These two studies are particularly helpful for us to understand how some social commerce website features may impact social shopping activities. However, to our knowledge, there has been no systematic investigation that maps social commerce features and discusses how these technical features are incorporated over time into e-commerce retailers' websites to support their online business models and strategies in social commerce.

We believe that technical features are responsible for supporting information sharing and social interaction thus are important enablers of new ways of online commerce (Grange and Benbasat 2010). A better analysis of the evolution of the technical features can provide great insight into the transformational nature of e-commerce into social commerce.

Applying a longitudinal qualitative approach, this study examines the evolution of technical features on e-commerce websites to demonstrate how these sites progressed over time and transformed into more social commerce-oriented platforms. Five popular U.S-based e-commerce websites (Amazon, eBay, Overstock, Wal-Mart and Target) are analyzed based on their historical website versions retrieved through the Wayback Machine (available at archive.org) over the course of twelve and a half years. We aim to answer the following questions: (1) How has each of the top five e-commerce websites evolved over time in terms of their technical features?, and (2) How have these websites, collectively and individually, transitioned or transformed from an e-commerce approach to a more social commerce orientation?

Section 2 offers a brief overview of e-commerce and social commerce. Then Section 3 presents a conceptual framework that categorizes e-commerce activities according to three different emphases: transactional, relational and social. Section 4 discusses our methodology, and reports on the e-commerce websites that we sampled, our data collection procedure, and the categorization of different technical features. Section 5 presents and discusses our findings. Finally, we draw a number of conclusions, and highlight some practical and theoretical implications of our study. 


\section{AN OVERVIEW OF E-COMMERCE AND SOCIAL COMMERCE}

With Web 1.0 and other Internet based technologies came the rise and fall of e-commerce. The failure of a large number of online companies during the collapse of the dotcom bubble between 2000 and 2001 (Cassidy 2002) demanded that firms should re-examine their strategies to operate and sustain virtual channels and develop a better understanding of consumer behavior, and customer loyalty and retention (Machado 2005). Web-based businesses started implementing new functionalities in their websites to enhance word-of-mouth advertising, build loyalty and retain clients, as well as to allow consumers to experience online shopping in a more social and interactive way. Supported by emerging technologies associated with Web 2.0 and massive adoption in the marketplace of social networking services, e-commerce began to experience a paradigm shift with the rise of social commerce.

Despite some empirical evidence that some web-based businesses implemented features to enhance social interaction and collaboration among consumers in the late 1990s (Curty and Zhang, 2011), the expression social commerce is officially credited to Yahoo! This occurred with the launching of two social commerce tools: Shoposphere and Pick Lists (Yahoo! 2005). Social commerce can be understood as a technology-enabled environment in which consumers can interact in social shopping activities, such as product search, product information sharing and aggregation, and collaborative decision-making (Shen and Eder 2011). These social features carry unique and interesting capabilities for online shopping (Grange and Benbasat 2010). Examples of features that support these social shopping activities are: wish lists, discussion forums, chat rooms, geo-tagging and geo-locators, blogs, podcasts, tagging, social networks, ranking tools, and recommendation systems (Jascanu et al. 2007). Also, some social commerce websites allow consumers to shop in an environment similar to social networking platforms, combined with one or more remotely-located shopping partners (Leitner et al. 2007).

Social commerce is beneficial for both consumers and merchants (Hajli 2012). Merchants can explore alternative revenue models and make more profit by attracting potential buyers via recommendations and consumer interactions, which can be established in social networks and collaboration environments. Firms can strengthen their ties with their partners and sustain better relationships with customers, foresee market 
trends, and identify new business opportunities. Social commerce also serves as a strategy for monetizing social media by the application of a two-way strategy: helping people connect where they usually buy, or guiding people to buy where they usually connect (Marsden 2010).

Since it is still relatively new, the term social commerce is not always used with consistency (Liang and Turban 2011). Some refer to it in the short form of s-commerce, and other terms, such as collaborative shopping and social shopping, are often used interchangeably. Nonetheless, in agreement with Rad and Benyoucef (2011), we believe that social commerce differs in scope when contrasted to social shopping or collaborative shopping. Social commerce encapsulates both seller and buyer networks, as well as the platforms where shopping activities and the related interactions take place. As a result, social commerce should be considered as being broader than the act of sharing shopping experiences with others.

\section{A CONCEPTUAL FRAMEWORK FOR THE EVOLUTION OF E-COMMERCE}

In searching for an approach to understand different online commerce emphases, we turned to marketing strategies that have been developed in the past. After all, the main purpose for company websites over the years has been to further their success with marketing. Marketing strategies are shaped by the overall goals of business, and they help to define the appropriate business and revenue models that have direct impacts on business returns. Two main types of marketing strategies addressed by the academic literature are transactional marketing and relationship marketing. They are often compared and contrasted, but others view them as simultaneous and complementary commercial strategies (Auruškevičienė et al. 2007, Zineldin and Philipson 2007). They also can be applied to both online or offline contexts.

Rouse (2009) defines transactional marketing as “a business strategy that focuses on single, 'point of sale' transactions. The emphasis is on maximizing the efficiency and volume of individual sales, rather than developing a relationship with the buyer.” Transactional marketing is primarily a profit-oriented strategy, wherein tactics are put in place to establish one-time exchanges with consumers. Transactional marketing gives priority to effective trading and sales, as well as interactions and transactional exchanges involving “single, short time exchange with a distinct beginning and ending” (Rao and Perry 2002, p. 59). 
In contrast, relationship marketing focuses on establishing and sustaining networks between firms and consumers, or between firms and business partners, emphasizing long-term lasting relationships. Rao and Perry (2002, p. 599) state that relational exchanges entail "multiple linked exchanges, extending over time,” which are often associated with “economical and social bonds.” As Li and Nicholls (2000) point out, relationship marketing involves planning for the exchange process beyond the exchange itself for higher levels of joint participation. This strategy also presents a more considerable level of mutual interest from the parties involved, and entails more persons and more primary personal relations. In this manner, the relationship marketing approach recognizes that the value of customer loyalty and cooperative alliances with other firms is not driven by immediate profitability concerns (Auruškevičienė et al. 2007, Hastings 2003). Instead, it is oriented toward creating and maintaining long-term relationships, and achieving sustainable profitability. Based on the assumption of mutual benefits, relationship marketing became known for supporting companies’ stability and permanent competitive advantage.

With the development of the Internet economy and the growth of social media, scalable communication and ubiquitous accessibility make a third commercial marketing strategy relevant: social media marketing. According to Qualman (2010), this term was coined in 2006 by Rohit Bhargava, a digital strategist and marketer, to represent the strategy of leveraging user-generated content as a basis for establishing mechanisms that engender trust by offering endorsements. Social media marketing seeks to build engagement through interactions and to promote communication among potential consumers and existing customers in interactive communities to improve traffic and sales (Gillin 2008). Social media marketing is motivated by the opportunities and potential returns brought about by consumer socialization and engagement. Practitioners have viewed this as the movement of marketing toward the "social Web" (Weber 2007). Likewise, Evans and McKee (2010) consider social media marketing as the next generation of business engagement. It relies on the development of the social ecosystem that online companies are a part of, and the importance of companies to explore this environment to foster brand awareness and recognition, attract potential customers, and take advantage of user-generated content to support business strategy and value-generating analysis. 
The three marketing strategies we have discussed can be employed by e-commerce businesses to emphasize three strategies that may lead directly or indirectly to profit via content sharing and trading activities. The three strategies can coexist in the same commercial environment and are potentially applicable to any type of e-commerce business. Figure 1 summarizes the strategy emphases and the relationships among merchants, consumers and customers.

\section{INSERT FIGURE 1 ABOUT HERE}

Merchants represent business companies and sellers who offer services or products for profit. Consumers represent, in a broader way, people who intend to purchase, or may acquire goods or services for use or ownership. Customers represent shoppers who have conducted at least once some sort of business transactions with merchants. In other words, consumers are potential customers, whereas customers will have gone through the act of shopping at a particular merchant.

The transactional emphasis can be established among merchants (B2B) or between merchants and customers (B2C) with the focus on immediate sales. The relational emphasis occurs among merchants (B2B) or between merchants and customers (B2C or C2B) with a focus on potentially recurring customers for long-term and continued purchases. Merchants explore ways to identify business partners’ and customers' profiles, shopping habits and preferences, and establish customer relation management strategies for trust and loyalty. These relationships add value to the transactional emphasis, and integrate networks for non-monetary trades and monetary exchanges that may result from this relationship building.

The social emphasis involves primarily $\mathrm{C} 2 \mathrm{C}$ exchanges with the focus on communication and collaboration among customers and consumers. User-generated content creation, exchange, and use are the key characteristics in this e-commerce emphasis, as indicated by the information icon in Figure 1. Consumers interact with customers to obtain information about products and services, merchants' reputations, and other experiences associated with the transactions. Customers may generate reviews that are capable of exerting influence on other consumers or customers in their purchasing decisions. To enhance this ecommerce emphasis, merchants provide platforms for such communication and collaboration, and incorporate social media and social network features into their websites. 
The three emphases relate to each other in terms of transforming consumers into customers and leading to the ultimate profit-making goal in an iterative fashion. For example, business transactions give customers the sources of information that they can provide to others in the relational emphasis, in which consumers may eventually make purchases after reading the reviews or after exchanging ideas with customers. In Figure 1, this is represented by the thin line between the transactional and social emphases (Transactional $\leftrightarrow$ Social). Customers in the social emphasis may become those who will maintain a long-term relationship with the merchants. It is the merchants' desire that loyal customers are more likely to spread good word-of-mouth through comments and reviews in social media and social networks (Social ↔ Relational), which will garner the attention of more consumers who made transactions one time in the past (Social $\leftrightarrow$ Transactional), or will become recurring customers (Social $\leftrightarrow$ Relational). Steadier customers are likely to make more purchase transactions (Relational $\leftrightarrow$ Transactional).

Based on our conceptualization of the three e-commerce strategy emphases, and in agreement with the belief that the re-creation of online business strategies is influenced by the functionalities offered on the platforms (Ickler et al. 2009), we posit that technical features in e-commerce websites can be examined according to their ability to support the different strategic emphases. Table 1 defines the three types of technical features that can be found in e-commerce websites. This classification will be used in our longitudinal analysis of the website features of a selected set of e-commerce websites.

\section{INSERT TABLE 1 ABOUT HERE}

\section{METHODOLOGY}

The phenomenon investigated in our study is the inception of various new technical features at different e-commerce websites over time. For such an investigation, the longitudinal quality method is appropriate. Longitudinal qualitative studies are useful for investigating and interpreting changes in processes over time in different social contexts (Holland et al. 2006). According to Ruspini (1999), longitudinal study methods involve three main requirements: (1) data should be collected at least in two different periods of time; (2) the cases that are studied have to be similar or broadly comparable; and (3) data analysis 
should involve some comparison of data across the different periods.

The sample websites in our study were chosen based on the results of a survey deployed through the Mechanical Turk hosted by Amazon.com. A total of 100 workers, including 59 females and 41 males between 18 to 64 years old located in the United States, participated in this task. They had an average of five hours of online shopping activity per week. Each participant was asked to indicate in an open-ended answer format and in order of preference three U.S. websites at which they shopped frequently. Respondents received a monetary incentive in U.S. dollars for completing the survey.

From the 300 website responses, Amazon, eBay, Wal-Mart, Target and Overstock were the top five websites mentioned. These websites also were in the top twelve of fifty websites in a 2011 ranking by the National Retail Federation (2011). This cross-validation ensured that the five sample websites selected are among the popular and successful ones in the vast universe of e-commerce websites. See Table 2.

\section{INSERT TABLE 2 ABOUT HERE}

Except for eBay, which is classified as an online marketplace, the other four companies are considered to be general merchandise companies. Among them, Wal-Mart and Target operate in both the online and brick-and-mortar environments.

We collected retrospective longitudinal data via the WayBack Machine Internet Archive (archive.org)during January, February and March 2012. The Wayback Machine is recognized as a valuable tool to track and investigate the evolution of websites. This is useful for longitudinal studies, since the World Wide Web is a changing environment (Murphy et al. 2007). The Internet Archive Initiative, a nonprofit organization responsible for curating a digital library of Internet sites, has maintained the Wayback Machine since 1996. It captures and stores screenshots over the lifetime of a URL, which preserves different versions of websites over time, and organizes them in a calendar fashion by years, months and days.

Our data pool includes Wayback Machine screen captures starting from January 1999 until June 2011, a twelve and a half year period. For every year of activity for each website, we retrieved quarterly screen captures. We explored the first screen capture available within each quarter of a given year, and 
identified, listed and described all of its features in a spreadsheet. Our data set includes a total of 250 website screen captures, or fifty per website.

A feature of a website is an attribute that is prominent, conspicuous or characteristic, and creates a special attraction (Free Online Dictionary of Computing 2010). In the present study, features include functions, tools, plug-ins, services and applications that have clearly identifiable purposes to support online business and commercial activities, as well as user interactions with merchants and other users.

During the data collection, we recorded each identified feature in a spreadsheet, along with its website and year of introduction. Whenever it was available, a description explaining the purpose of the feature was included. In some cases, additional searches were conducted about various features and their corresponding websites in order to identify trade articles or business announcements that could provide additional information about the implementation of the features. We excluded shopping bags, shopping carts and similar features from the list. These are essential features for all e-commerce websites. We identified a total of 174 distinctive features in the five websites. Among the 174 features, 32 or $18.4 \%$ appeared in more than one website. (See Appendix A.)

Each feature was then coded according to the e-commerce strategic emphasis, attributing only one code per feature. (See Table 1 again.) To ensure reliable coding, we invited two additional independent coders to re-examine and re-classify each of the features. A rate of 73.5\% agreement was achieved after the first round of coding, and $100 \%$ in the second round of coding.

\section{FINDINGS}

\subsection{An Overview}

Appendix A lists all 174 features, their introduction dates and websites, brief descriptions, and their strategic emphasis categories. Table 3 lists the total number of new features identified in each of the three categories across the five websites over the twelve and a half year period. Among the five websites, eBay presented the highest number of social commerce features (30\%), followed by Amazon (26\%). Amazon leads with the highest number of transactional features introduced and eBay leads in the social and rela- 
tional features categories. The total number of relational features surpasses the other two combined.

\section{INSERT TABLE 3 ABOUT HERE}

Figures 2, 3 and 4 illustrate the introduction of the new features in the three categories over the years in the five websites.

\section{INSERT FIGURES 2, 3 AND 4 ABOUT HERE}

For the transactional features, there was a peak for the introduction of new ones in 2008. The distribution of relational features, which have been stable over the years, had the lowest number of new introductions between 2007 and 2009. The social features had a similar peak, though it came one year earlier in 2007. eBay and Amazon were the early birds in incorporating new social features in 1999; the other three websites did not have any social features until 2002. Between 2000 and 2001, however, there was a noticeable gap in the introduction of new social features, while there was a decline in the final three years.

Figure 5 offers a timeline visualization of features introduced by the five websites. Separate representations for each of the five websites are shown in Appendices B, C, D, E and F. The social features are located above the timeline and denoted by circles $(O)$. Relational features are right below the timeline and indicated by triangles $(\triangle)$. Transactional features are toward the bottom and marked with squares ( $\square$ ). The distances between the features are for convenience only and are not meaningful. A new feature that was introduced in the same year at different websites is identified with the different websites where the feature was introduced. In cases where there was a similar feature that was introduced in different years, only the first appearance of the feature is shown.

The results affirm our assumption that the three emphases - transactional, relational and social - coexist and evolved at different points of time through the implementation of new features to support the firms’ marketing strategies and business models.

The figure also shows the following transactional features that were introduced: dedicated order tracking, currency conversion, product and services auctions, money transfers, faster checkout, product search, sales parameters and indicators, and optional multi-channel access to the platform, such as smartphones. These features have modernized the online transaction-making process and have assured a 
more secure environment. For the relational features, different features have appeared over the years, including: website personalization, live shopping assistance, historical searches, rewards and affiliation programs, product alerts, reminders and recommendations from the website.

Related to the social features, Overstock added Facebook and Twitter features in 2009, followed by Wal-Mart and Target a year later. All three websites adopted features such as "Like Us on Facebook" and "Follow Us on Twitter," with the intention to gather more followers and friends who were exposed to their announcements and news. Overstock and Target also connected with YouTube in 2010. The same year, Overstock incorporated the function “Tweets about Overstock” by aggregating and displaying on their homepage tweets generated about Overstock in microblog services. The company also began to make use of user-generated content to better support its social emphasis.

The timeline further reveals differences among the technical features that we identified. Some features are simpler, such as reviews, ratings and polls, while others are more complex and incorporate several different functions into one. Examples include "Neighborhoods," "Purchase Circles,” and the "eBay Café.” Among the five websites, Amazon, eBay and Overstock seem to have incorporated more of these features in their platforms, usually carrying the name of the company in these features.

\subsection{The Transformation to Social Commerce and the Evolution of Social Features}

The implementation of social features supports the third e-commerce emphasis, which relates more directly to social commerce. Next weprovide more details about the social features that we identified for the years that our data cover in chronological order. Then, based on the analysis of each social feature's purposes, we classify the social features into different categories to gain more insight. Although we initially thought that the social emphasis in e-commerce started receiving greater attention from 2005 onwards, our results show that eBay and Amazon were pioneers in implementing social features in their platforms much earlier than 2005 in the late 1990s.

\subsubsection{Late 1990s Endeavors}

In 1999, Amazon and eBay launched four important social features: “Purchase Circles,” Amazon’s “Listmania,” the "eBay Café” and the "FeedBack Forum.” All had the main goal of community building. 
The "Purchase Circles” feature was announced as a service to help shoppers find the most popular products in different cities, universities and workplaces with the purpose of assisting users' personal buying decisions and promoting more informed purchases. According to Hafner (2000), this service was intended to enable customers in different groups to search for popular products, especially books. Readers also were able to learn about the buying preferences of people with whom they shared interests or characteristics. Also, people could obtain insights about a place, a location or an organization by observing related sales trends. In 2007, the service was discontinued and Amazon's website announced that this feature was undergoing a major renovation. Until now, the feature has not been re-launched. Cleverly (2007) has speculated that the service had to be revaluated due to information privacy concerns, because it was a vast and open source for data mining.

"Listmania” from Amazon allows a customer to share compiled lists of products with other consumers. This feature is still active, although its purpose overlaps to some extent with traditional wish lists. Amazon continues to use "Listmania” and wish list features. Wish lists are designed for personal tracking of desired products with different privacy settings, while "Listmania” lists are searchable and accessible to any user of the platform.

The "eBay Café” was originally launched as a discussion board to support chatting among members of the eBay community. This feature remains active at eBay's website. Despite advances in eBay's functionality and interface design over the years, the mechanics of the "eBay Café" feature remain the same. Users can interact with other members related to ongoing discussion topics in existing threads, or they can create new ones. Currently, messages can be tweeted or shared via Google Plus. Users also can follow new threads and updates through the RSS feature, and contribute to polls with votes and participation.

Another feature that eBay has consistently offered since 1999 is the "FeedBack Forum,” a space for reputation building where trading partners are rated and reviewed. Different from products or services ratings and reviews, this service focuses on developing member profiles and helping prospective trading partners be involved in buy and sell transactions with greater confidence.

In 1999, these four features were aligned with Hajli’s (2012) and Marsden’s (2010) perspectives on 
the two-way value-creating capabilities of social commerce. The importance of building virtual communities was a salient driver of the introduction of the features we have described. They empowered social interactions among consumers and created valuable user-generated content to support the companies that launched them. Schubert and Ginsburg (2000) recognized three major forces associated with e-commerce community building: (1) to strengthen trust in trading activities and establish a more warm and social environment for consumers; (2) to provide mutual support and the means for the identification of individual user needs based on shared community knowledge; and (3) to increase consumer buying power while collecting potential ideas for group-tailored products and services, in order to extend existing product bases.

As we previously noted, between 2000 and 2001 there were no new social features that were introduced in the five websites. This coincides with the time when numerous online retailers were victims of the burst of the dotcom bubble (Cassidy 2002). Thus, one possible explanation for this apparent lack of interest is effect of the crisis period for online businesses. Some retailers probably preferred to continue their operations and not take additional risks by releasing new social features on their platforms.

\subsubsection{The Resurgence of Social Features}

From 2002 to 2006, however, new features that support social shopping and interactions among customers surged to greater attention. The inclusion of recommendation agents in websites became widespread, in order to elicit the interests and shape the preferences of consumers. Websites started implementing reviews and ratings, $\mathrm{C} 2 \mathrm{C}$ recommendation functions, spaces for customers to create and share shopping guides, and tools to allow customers to check and search for related products. All of these are based on other customers shopping activities and experiences.

In 2002, Wal-Mart launched “Connect and Share,” where consumers could interact in a Q\&A forum, organized by topics, through posting their stories and shopping experiences. The questions could be answered by other shoppers or Wal-Mart representatives. When we conducted this analysis in early 2013, this feature remained active in Wal-Mart's website. In the same year of 2002, “Friends and Favorites” was released by Amazon. This feature allowed users to get product information from people with whom they were friends. They were able to build their personal social networks with favorite people and follow 
their opinions and recommendations. Two other features have similar purposes of showing consumers alternatives of products that are associated to the products they are searching and visualizing: "Customers Who Bought This Also Bought” was first introduced by Amazon and Target in 2004, and "Customers Who Viewed This Also Viewed” was launched in 2006 by Overstock. These features tool into account previous customers' activities and had the goal of stimulating shoppers to buy more by exposing them to a set of additional products most relevant to their purchase intentions. These two features used filtering systems in a collaborative and social way by gathering information from users' behaviors in a more implicit fashion (Kangas 2002). Different from situations where consumers explicitly created and shared contents with others in writing reviews or ratings, these social features gauged more implicit behaviors captured through actions of consumers during the use of different features of the websites.

Surprisingly, our timeline, as shown in Figure 4, reveals just one new social feature in 2005, Guides from eBay. It was implemented to enable eBay members to share their expertise on any topic or category. The motto, “Write and Share, Read and Learn,” was used by eBay as a way to emphasize how others’ experiences can support more informed shopping decisions.

\subsubsection{The Year 2007: The Apogee of Social Commerce}

Although the term social commerce was coined in 2005, our data show that the peak year for the emergence of new social features was two years later in 2007. eBay alone launched seven social features to support customer collaboration and socialization. This matches the findings from another study, which suggested that social commerce began to grow more rapidly in that year (Wang and Zhang 2012). In addition, to support content creation, eBay launched wiki spaces and blogs so that members could create articles, share contents and swap pictures. Members of eBay were able to build personalized spaces and develop personal profiles to connect and share information with other members through its “eBay My World” service. They also can create social voting polls with eBay matchups, participate in mentoring groups and receive help from eBay members on the platform for better shopping and selling experiences.

Additionally, eBay incorporated word clouds based on user-generated content through tagging activities, and released “Neighborhoods.” According to Steiner (2007) and Sacco (2007), Neighborhoods aimed 
to create micro-communities built around common interests. This feature drew content from blogs, reviews and guides, and allowed neighborhood-specific message boards and member-uploaded photos. It offered social mapping tools to visualize the interconnections among people and their common interests.

In October 2011, eBay announced its plan to remove “Neighborhoods.” By April 30, 2012, the feature disappeared and its functions were incorporated into the “Groups” feature. Also in 2007, Overstock released “OMUSE,” a wiki-based collaborative and open environment through which customers with similar interests could find each other and team up in group activities and projects. Overstock's intention was to create constantly evolving guides with practical and applied knowledge to support its customers. However, this feature is no longer active in the company’s website. After “OMUSE” was discontinued, Overstock's emphasis on building a sense of community among customers re-emerged in 2008 with the release of its "Community” feature. This was a portal in which registered users could explore different social tools, such as discussion boards, groups and forums. Overstock’s announcement of this feature made its purpose clear: "[P]eople like you can interact, entertain and educate ... When we're finished, you'll be able to keep up on current events, speak your mind on your free blog, chat with folks like you in our forums, and work with others to write the book on the activities that most inspire you. Big changes are coming fast, so please check back soon." In 2010, this feature was redesigned and social networks services were incorporated into it for integrating users and maximizing word-of-mouth.

In 2006 Amazon launched “Amazon Plog.” The basic idea of “Plog” was to customize a blog for customers based on their past purchases and click behavior. In order to promote more social interactions among customers and keep them updated with new products and services offers, in 2007 Amazon released another revamped blogging platform called “Amazon Daily.” It provided customers with information on trendy products and services, as a way for customers to comment on the highlights for the blog. Amazon Daily drew its contents from different Amazon editorial blogs and amassed them into a single repository from which Amazon shoppers could get their news. The Internet-based newsletter, Digital Trends, reported that “Amazon Daily” offered "a degree of personalization which allows users to select which topics are displayed, quick links to other Amazon blogs, easier navigation of ‘Amazon Daily’ ar- 
chives, and commenting and voting on posts” (Digital Trends Staff 2007).

\subsubsection{The Plateau Stage}

Between 2009 and the first half of 2011, there was a clear decline in the launch of new social features at the websites we tracked. Among the few that occurred, in 2009 Overstock launched “O.biz” for businesses and customers to trade merchandise in bulk. This was announced as a feature that was designed to give small businesses and customers the opportunity to buy large quantities of merchandise at deep discounts. Later, “O.biz” was redefined as a parallel B2B website, and it remains active today.

In 2010, Amazon introduced “Connecting with Facebook.” This alliance was motivated by the possibility of bringing in potential new shoppers that are part of its customers' networks. The main idea is to allow consumers to tap into their Facebook friends and get recommendations to discover what their friends' favorites and likes are.

In 2011, eBay launched “Group Gifts,” a collective buying function to support friends who would like to give gifts together. Members are able to set up a group gift using Facebook or email, chip in to pay, and track payments from members and collectively purchase gifts.

\subsubsection{Social Features: A Functional Categorization}

A closer analysis of the 42 social features found in the top five e-commerce websites allows us to categorize these different features by associating their common purposes based on the business strategy they support. In general, all social features have the main goal of promoting interactions and social exchanges among consumers to improve their shopping experience. We also can infer that there are similarities in the purposes of the different features that have been introduced by different websites across the years.

Our analysis identified four main categories that are primarily dedicated to: (1) attracting others and promoting branding; (2) building users' identities while strengthening member ties to the community; (3) producing user-generated content for further use; and (4) promoting collective action. Table 4 summarizes these four categories and offers some examples.

\section{INSERT TABLE 4 ABOUT HERE}

The proposed categories summarize and integrate the common purposes of different social features 
that we identified. They consider the features underlying the functions and strategies that characterize the evolution to a more social-oriented type of commerce. Because it is critical for any social commerce website to offer a minimum of social features, this compilation can serve as a guideline for the identification of the implementation of new capabilities and new features.

\section{CONCLUSION}

This study answered two questions related to the evolution of the top five e-commerce websites and their transitions to a more social commerce orientation. We examined the websites' individual and collective evolution over twelve and a half years, and traced the introduction of different technical features across the years. 174 newly-introduced features were identified and classified based on their support for various transactional, relational and social businesses strategy emphases. In addition, we provided a deeper examination of the social features to shed light on the transformation from e-commerce to social commerce. We outlined a framework to summarize the purposes and functionalities of the social features.

As a longitudinal and retrospective investigation, this study was limited by the availability and quality of WayBack Machine data, and faced some constraints for webpage navigation. Because of these things, and despite our effort to thoroughly analyze the websites, it still is possible that some features were not captured properly in our data collection process. Also, the descriptive and qualitative approaches that we used in this study, along with the small number of cases that we investigated, restrict us from offering more generalizable results that are applicable to the wider e-commerce sphere. Our classification of the websites’ social features was drawn up solely based on a meta-analysis of our empirical data.

In spite of the limitations, we discovered some interesting facts and trends. Although the term social commerce emerged in 2005, our study shows that Amazon and eBay introduced some social commercerelated features as early as late 1990s. They did this to empower C2C interactions and social shopping activities. They also sought to adapt their business strategies to the Internet economy and the increasing importance of online word-of-mouth. E-commerce has been evolving gradually and the three strategic emphases coexist, as evidenced by the supporting technical features that we reported on. There may be 
different degrees of social commerce, depending on the nature and extent of the supporting social features that are implemented at different e-commerce websites. And, since five websites that we studies represent companies with different business models, it will be interesting to assess and compare how their website features changed over the years as their e-commerce strategies evolved.

This study offers two major contributions. At the conceptual level, we proposed a framework to understand the three strategic emphases in e-commerce, and the interactions among the three major actors merchants, consumers, and customers. We also provided a categorization of social features to highlight the social commerce orientation of the top five e-commerce websites. At the methodology level, we demonstrated a qualitative longitudinal analysis that captures and analyzes historical evidence about the introduction of different transactional, relational and social features by top e-commerce websites.

\section{REFERENCES}

Amblee, N., and Bui, T. 2011. Harnessing the influence of social proof in online shopping: the effect of electronic word of mouth on sales of digital microproducts. International Journal of Electronic Commerce 16(2) 91-114.

Auruškevičienė, V., Kuvykaitè, R., and Škudienė, V. 2007. Relationship and transactional marketing integration aspects. Inzinerine Ekonomika-Engineering Economics 4(54) 78-86.

Cassidy, J. 2002. Dot.con: The Greatest Story Ever Sold. New York: Harper Collins Publishers.

Cleverly, M.A. January 20, 2007. Amazon's purchase circles: MIA? Cleverly Blogged. Available at blog.cleverly.com/permalinks/279.html.

Curty, R.G., Zhang, P., 2011. Social commerce: Looking back and forward. Proceedings of the American Society for Information Science and Technology 48, 1-10.

Digital Trends Staff. April 19, 2007. Amazon launches one blog to rule them all. Digital Trends, Portland, OR. Available at www.digitaltrends.com/lifestyle/amazon-launches-one-blog-to-rule-them-all.

Evans, D., and McKee, J. 2010. Social Media Marketing: The Next Generation of Business Engagement. Indianapolis, IN: Wiley Publishing.

Free Online Dictionary of Computing. 2010. Feature. D. Howe (ed.). Available at foldoc.org.

Gillin, P. 2008. Secrets of Social Media Marketing. Fresno, CA: Quill Driver Books.

Grange, C., and Benbasat, I. 2010. Online social shopping: the functions and symbols of design artifacts. In R. Sprague (ed.), Proceedings of the $43^{\text {rd }}$ Hawaii International Conference on Systems Science, January 2010, Washington, DC: IEEE Computer Society Press.

Hafner, K. May 21, 2000. Navigating the Amazon Circle. Books, The New York Times on the Web. Available at www.nytimes.com/books/00/05/21/bookend/bookend.html.

Hajli, M. 2012. Social commerce adoption model. In Proceedings of the $17^{\text {th }}$ U.K. Academy of Information Systems Conference. Atlanta, GA: Association for Information Systems. 
Hastings, G. 2003. Relational paradigms in social marketing. Journal of Macromarketing 23(1) 6-15.

Holland, J., Thomson, R., and Henderson, S. 2006. Qualitative longitudinal research: a discussion paper. Families and Social Capital Research Group, Economics and Social Research Council, London South Bank University, London, UK.

Huang, C.Y. 2011. Excess loyalty in online retailing. International Journal of Electronic Commerce, 16(2) 115-134.

Huang, Z., and Benyoucef, M. 2013. From e-commerce to social commerce: a close look at design features. Electronic Commerce Research and Applications.

Ickler, H., Schülke, S., Wilfling, S., and Baumöl, U. 2009. New challenges in e-commerce: how social commerce influences the customer process. Presented at the $4^{\text {th }}$ National Conference on Computing and Information Technology, Songkhla, Thailand.

Jascanu, N., Jascanu, V., and Nicolau, F. 2007. A new approach to e-commerce multi-agent systems. The Annals of "Dunarea De Jos" University of Galati, Fascicle III: Electrotechnics, Electronics, Automatic Control and Informatics, 8-11.

Kangas, S. January 1, 2002. Collaborative filtering and recommendation systems, version 1.0. Research report TTE4-2001-35, VTT Information Technology, Finland.

Kim, Y., and Srivastava, J. 2007. Impact of social influence in e-commerce decision-making. In R.J. Kauffman and M. Gini (eds.), Proceedings of the Ninth International Conference on Electronic Commerce, Minneapolis, MN, August 2007, New York, NY: ACM Press.

Leitner, P., Grechenig, T., Krishnamurthy, S., and Isaias, P. 2007. Community driven commerce: design of an integrated framework for social shopping. In S. Krishnamurthy and P. Isaisis (eds.), Proceedings of the IADIS International Conference E-Commerce 2007, International Association for the Development of the Information Society Press.

Li, F., and Nicholls, J.A.F. 2000. Transactional or relationship marketing: determinants of strategic choices. Journal of Marketing Management 16(5) 449-464.

Liang, T. P., Ho, Y.T., Li, Y.W., and Turban, E. 2011. What drives social commerce: the role of social support and relationship quality. International Journal of Electronic Commerce 16(2) 69-90.

Liang, T.P., and Turban, E. 2011. Introduction to the special issue - social commerce: a research framework for social commerce. International Journal of Electronic Commerce 16(2) 5-14.

Machado, A. 2005. Drivers of shopping online: a literature review. In Proceedings of the IADIS International Conference E-Commerce 2005, International Association for the Development of the Information Society Press.

Marsden, P. 2010. Social Commerce: Monetizing Social Media. Norderstedt, Germany: GRIN Verlag.

Murphy, J., Hashim, N.H., and O’Connor, P. 2007. Take me back: validating the Wayback Machine. Journal of Computer Mediated Communication 13(1) 60-75.

Olbrich, R., and Holsing, C. 2011. Modeling consumer purchasing behavior in social shopping communities with clickstream data. International Journal of Electronic Commerce 16(2) 15-40.

Pagani, M., and Mirabello, A. 2011. The influence of personal and social-interactive engagement in social TV web sites. International Journal of Electronic Commerce 16(2), 41-68.

Parise, S., and Guinan, P.J. 2008. Marketing using Web 2.0. In R. Sprague (ed.), Proceedings of the $41^{\text {st }}$ Hawaii International Conference on System Sciences, Waikoloa, Hawaii, HI, January 2008, Washington, DC: IEEE Computer Society Press. 
National Retail Foundation. 2011. 2011 favorite 50. Available at www.stores.org/2011/Favorite-50List?order=field_rank_value\&sort=asc\#.UWlQYyt4aFc.

Qualman, E. 2010. Socialnomics: How Social Media Transforms the Way We Live and Do Business. Hoboken, NJ: John Wiley and Sons.

Rad, A.A., and Benyoucef, M. 2011. A model for understanding social commerce. Journal of Information Systems Applied Research 4(2) 63-73.

Rao, S., and Perry, C. 2002. Thinking about relationship marketing: where are we now? Journal of Business and Industrial Marketing 17(7) 598-614.

Rouse, M. April 2009. What is transactional marketing? Search CRM, Newton, MA. Available at searchcrm.techtarget.com/definition/transactional-marketing.

Ruspini, E. 1999. Longitudinal research and the analysis of social change. Quality and Quantity 33(3) 219-227.

Sacco, N. October 9, 2007. Introducing eBay Neighborhoods. Available at www2.ebay.com/aw/core/200710091605092.html.

Schubert, P., and Ginsburg, M. 2000. Virtual communities of transaction: the role of personalization in electronic commerce. Electronic Markets 10(1) 45-55.

Shen, J., and Eder, L.B. 2011. An examination of factors Associated with user acceptance of social shopping websites. International Journal of Technology And Human Interaction 7(1) 19-36.

Steiner, I. October 10, 2007. eBay launches social networking with Neighborhoods. eCommerceBytes, Natick, MA. Available at www.ecommercebytes.com/cab/abn/y07/m10/i10/s03.

Wang, C., and Zhang, P. 2012. The evolution of social commerce: the people, management, technology and information dimensions. Communications of the Association for Information Systems 32, 1-23.

Weber, L. 2007. Marketing to the Social Web: How Digital Customer Communities Build Your Business. New York, NY: John Wiley and Sons.

Wigand, R.T., Benjamin, R.I., and Birkland, J.L.H. 2008. Web 2.0 and beyond: implications for electronic commerce. In Proceedings of the $10^{\text {th }}$ International Conference on Electronic Commerce. Innsbruck, Austria, August 2008, New York, NY: ACM Press.

Yahoo! 2005. Social commerce via the Shoposphere and pick lists. Available at www.ysearchblog.com/2005/11/14/social.commerce.via.the.shoposphere.pick.lists.

Zhou, L., Zhang, P., and Zimmermann, H.D. 2013. Social commerce: an integrated view. Electronic Commerce Research and Applications 12(2) 61-68.

Zineldin, M., and Philipson, S. 2007. Kotler and Borden are not dead: myth of relationship marketing and truth of the 4Ps. Journal of Consumer Marketing 24(4) 229-241. 
Table 1 - Technical features that support e-commerce emphases

\begin{tabular}{|c|c|}
\hline Category & Description \\
\hline Transactional & $\begin{array}{l}\text { Features that support activities related to agreements and concessions established between a } \\
\text { buyer and a seller to trade an asset/commodity. Example technical features are those related } \\
\text { to shipping tracking, product search and checkout tools. }\end{array}$ \\
\hline Relational & $\begin{array}{l}\text { Features that seek to forge new and/or maintain long-term relationships between merchants } \\
\text { and consumers and/or business partners. They support commitment, loyalty and trust building. } \\
\text { Based on consumers' and partner's information, location, profile and shopping habits, retailers } \\
\text { are able to tailor better relational strategies. Example relational features are: targeted promo- } \\
\text { tions, recommendations based on previous searches (browse history) or purchases, member- } \\
\text { ship/affiliation advantages and reward programs. }\end{array}$ \\
\hline Social & $\begin{array}{l}\text { Features that promote and support interactions between or among consumers/customers, } \\
\text { through which they are able to share opinions, experiences, comments about products/services } \\
\text { or merchants. The social activities may impact user generated content (UGC) and } \\
\text { crowdsourcing to support buying decisions, leverage sales (transactions) and forge recurring } \\
\text { customers (relationships). Social activities in e-commerce websites may take place in social } \\
\text { channels such as: forums, discussion lists, rankings, pools, ratings and reviews. }\end{array}$ \\
\hline
\end{tabular}

Table 2 - Websites analyzed

\begin{tabular}{lccccl}
\hline & & & & \\
& & & & & \\
Website & 1995 & 1 & 1 & General Merchandise & http://www.amazon.com \\
\hline Amazon & 1998 & 2 & 3 & Online Marketplace & http://www.ebay.com \\
eBay & 1999 & 3 & 2 & General Merchandise & http://www.walmart.com \\
Wal-Mart & 1999 & 4 & 7 & General Merchandise & http://www.target.com \\
Target & 1999 & 5 & 12 & General Merchandise & http://www.overstock.com \\
Overstock & 195 & &
\end{tabular}


Table 3 -Technical Features Identified

\begin{tabular}{lccccccc}
\hline Category & Amazon & eBay & Overstock & Target & Wal-Mart & Total & $\%$ \\
\hline Social (S) & 8 & 15 & 10 & 5 & 4 & 42 & $24 \%$ \\
Relational (R) & 20 & 25 & 19 & 14 & 16 & 94 & $54 \%$ \\
Transactional (T) & 17 & 13 & 3 & 3 & 2 & 38 & $22 \%$ \\
Total & 45 & 53 & 32 & 22 & 22 & 174 & $100 \%$ \\
\% & $26 \%$ & $30 \%$ & $18 \%$ & $13 \%$ & $13 \%$ & $100 \%$ & \\
\hline
\end{tabular}

Table 4 - Social Features' Categorization

\begin{tabular}{|c|c|c|}
\hline Category & Description & Some Examples \\
\hline $\begin{array}{l}\text { Promote } \\
\text { and } \\
\text { Attract } \\
\text { Others }\end{array}$ & $\begin{array}{l}\text { Focuses on bringing awareness and attention } \\
\text { about deals, brands, and or new products. The } \\
\text { integration with third-party SNSs is an option to } \\
\text { expand the word-of-mouth to a broader scope. }\end{array}$ & $\begin{array}{l}\text { - E-mail to a friend - Overstock (2002); Target } \\
\text { (2003) } \\
\text { - Friends and Favorites - Amazon (2002) } \\
\text { - Tweets about Overstock - Overstock (2010) } \\
\text { - Connecting to Facebook - Amazon (2010) }\end{array}$ \\
\hline $\begin{array}{l}\text { Create Self- } \\
\text { Identity } \\
\text { and Sense } \\
\text { of Commu- } \\
\text { nity }\end{array}$ & $\begin{array}{l}\text { Allows users to create their identities in an in- } \\
\text { ternal community by personalizing a profile in } \\
\text { the website platforms. Users can socialize and } \\
\text { interact with others by exchanging ideas and } \\
\text { opinions with community members. }\end{array}$ & $\begin{array}{l}\text { - Purchase Circles - Amazon (1999) } \\
\text { - eBay Cafe - eBay (1999) } \\
\text { - Community - Overstock (2008) } \\
\text { - Connect and Share - Wal-Mart (2002) } \\
\text { - eBay Blogs - eBay (2007) } \\
\text { - eBay Cafe - eBay (1999) } \\
\text { - eBay my World - eBay (2007) } \\
\text { - FeedBack forum - eBay (1999) } \\
\text { - Neighborhoods - eBay (2007) } \\
\text { - OMUSE - Overstock (2007) } \\
\text { - Guides - eBay (2005) } \\
\text { - Listmania - Amazon (1999) } \\
\text { - Mentoring Center - eBay (2007) }\end{array}$ \\
\hline $\begin{array}{l}\text { Generate } \\
\text { Content }\end{array}$ & $\begin{array}{l}\text { Targets the creation of user-generated content } \\
\text { (UGC) to support other consumers in their } \\
\text { shopping decisions and, meanwhile, provide e- } \\
\text { commerce websites with strategic information } \\
\text { for projecting and anticipating trends. It can be } \\
\text { directly generated by customers in an active } \\
\text { way, where customers directly rate, tag or write } \\
\text { reviews, or in a passive way by consumers' be- } \\
\text { haviors. }\end{array}$ & $\begin{array}{l}\text { Active } \\
\text { - Word Clouds - eBay (2007) } \\
\text { - Ratings - Target (2003); Wal-Mart (2008); } \\
\text { - Review feedback - eBay (2003) } \\
\text { - Reviews - Overstock (2002); Target (2003) } \\
\text { - Reviews' evaluation - Overstock (2010) } \\
\text { - Video Reviews - Amazon (2007) } \\
\text { Passive } \\
\text { - Customers' favorites - Overstock (2004) } \\
\text { - Customers who bought this book also bought - } \\
\text { - Amazon (2004) } \\
\text { - Customers who viewed this also viewed - Over- } \\
\text { stock (2006) }\end{array}$ \\
\hline $\begin{array}{l}\text { Act } \\
\text { Collectively }\end{array}$ & $\begin{array}{l}\text { Focuses on supporting effective collective ac- } \\
\text { tions, where shoppers can get involved in activi- } \\
\text { ties designed for group participation. }\end{array}$ & $\begin{array}{l}\text { - eBay Matchups - eBay (2007) } \\
\text { - Group Gift - eBay (2011) } \\
\text { - Pools - Overstock (2004) }\end{array}$ \\
\hline
\end{tabular}


Figure 1 - Three e-commerce strategic emphases and relationships among involved parties

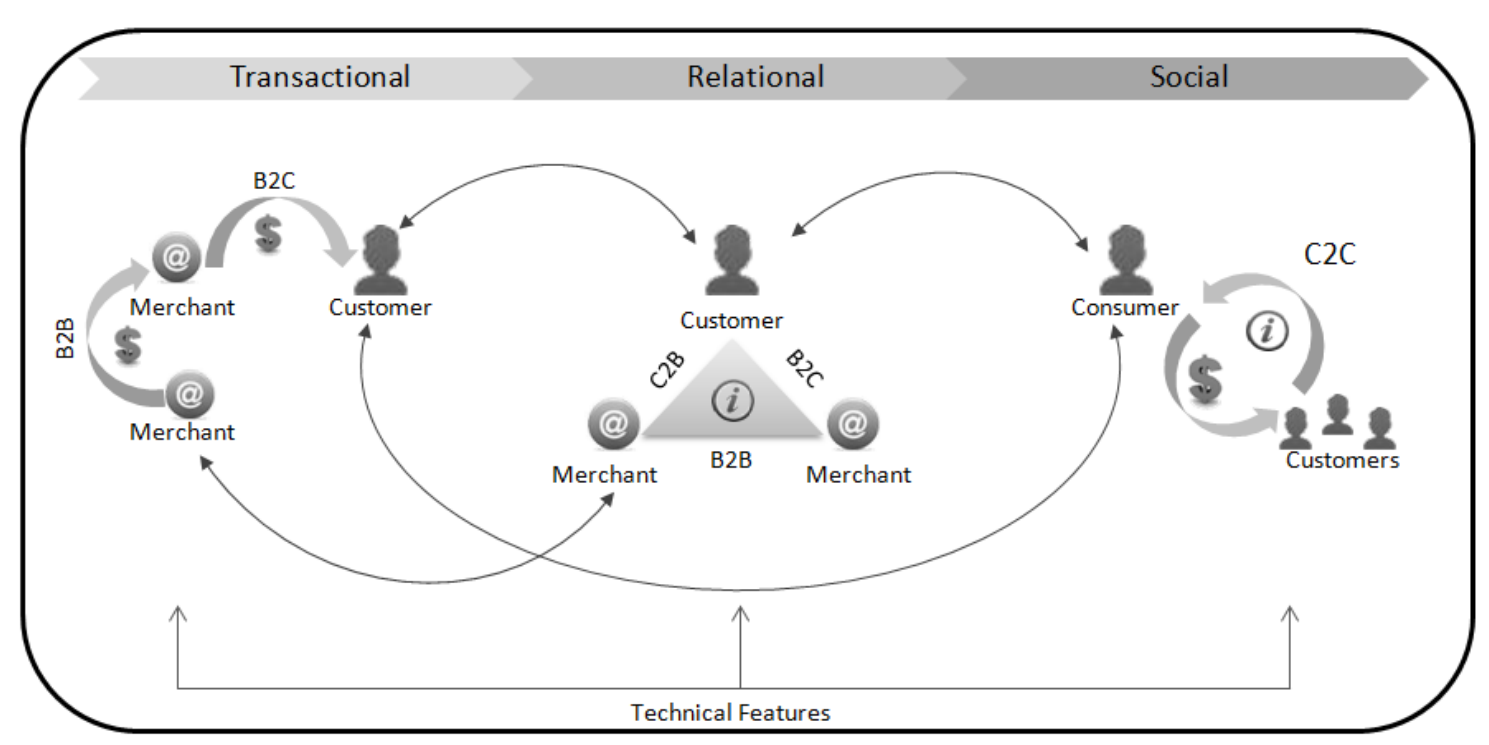


Figure 2 - Transactional Features over the Years

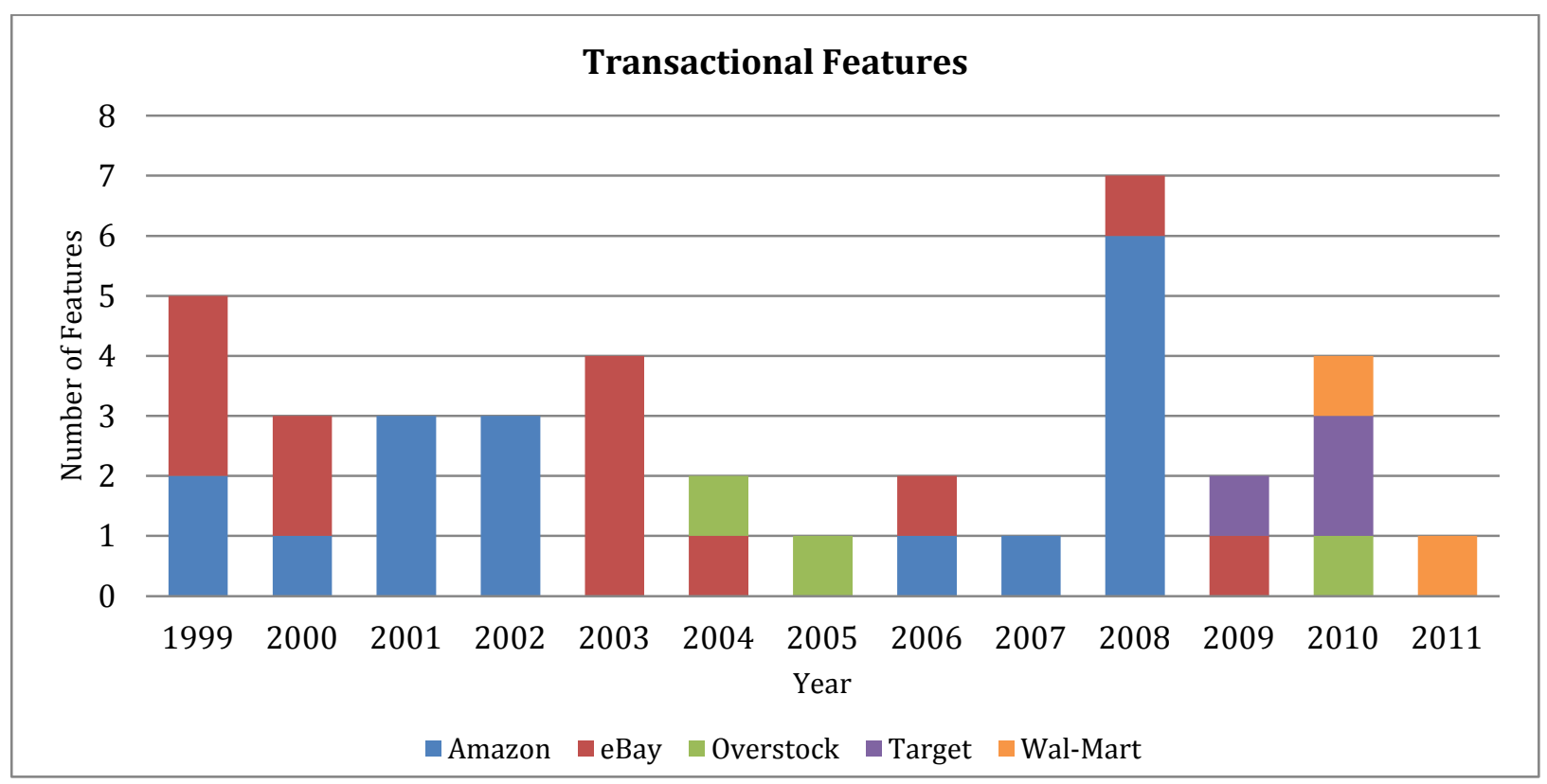

Figure 3 - Relational Features Over the Years

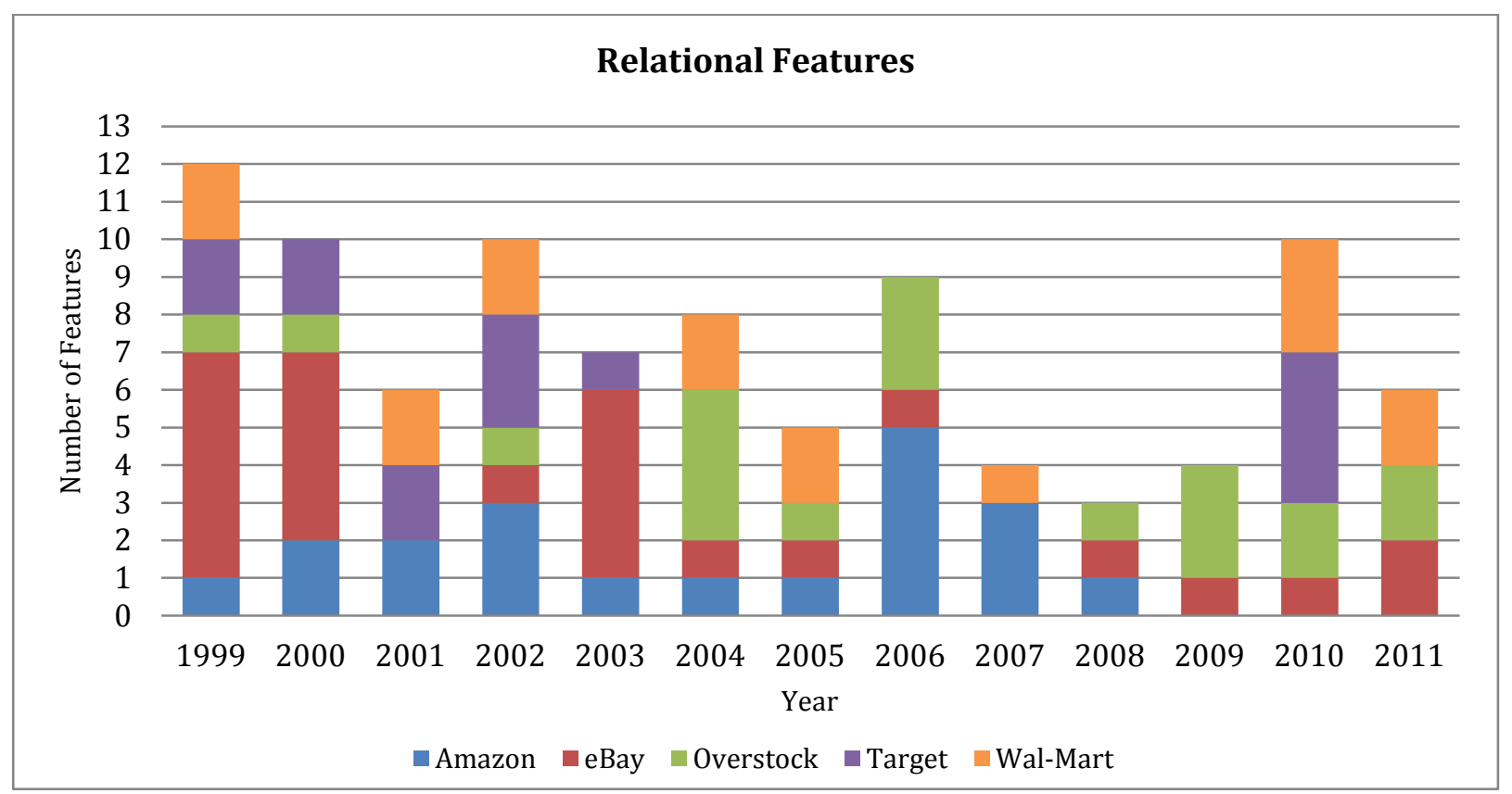


Figure 4 - Social Features over the Years

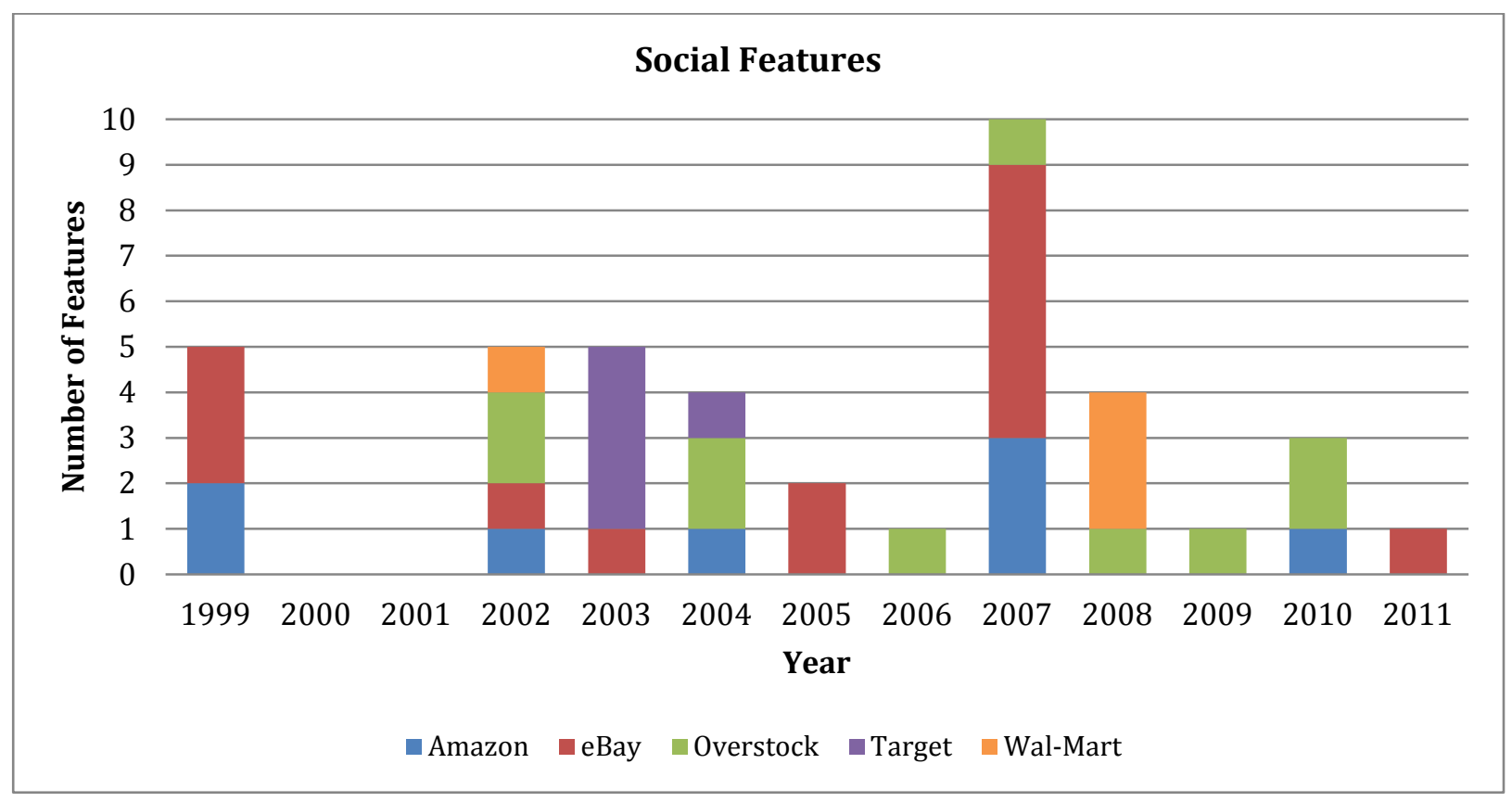


Figure 5 - Collective Timeline of New Feature Inception

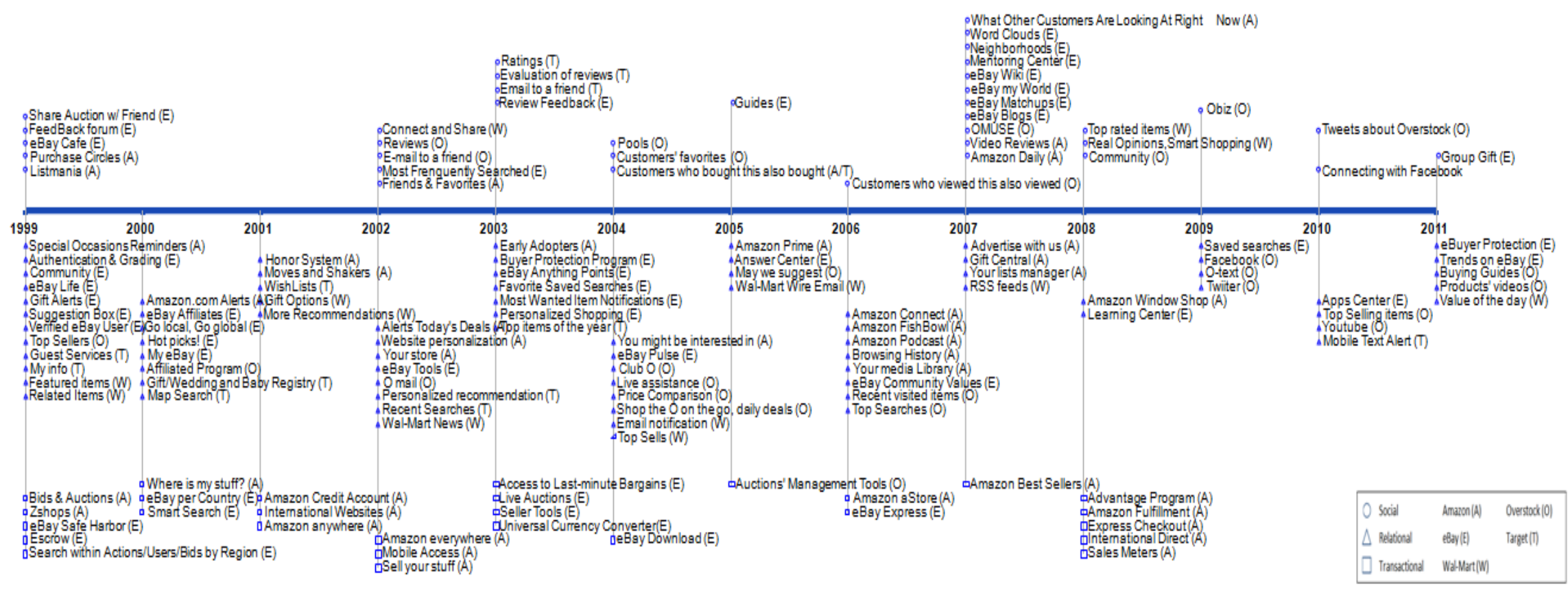




\section{Appendix A - List of Features}

\begin{tabular}{|c|c|c|c|}
\hline Feature & Website (Date) & Description & Final Code \\
\hline $\begin{array}{l}\text { Access to last-minute } \\
\text { bargains }\end{array}$ & eBay (2003) & Exclusive to registered users. Not possible to retrieve specifications. & $\mathrm{T}$ \\
\hline Advantage Program & Amazon (2008) & $\begin{array}{l}\text { A self-service consignment program that enables people to promote and sell media products directly on Amazon.com. Ad- } \\
\text { vantage is designed specifically for publishers, music labels, studios, authors, and other content owners who would like to } \\
\text { source their products to Amazon.com, the world's leading on-line retailer. It gives you the opportunity to market products to } \\
\text { millions of customers. The program offers a proven means of distribution and order fulfillment for media product (such as } \\
\text { books, videos, and music). The Advantage program is not intended for individuals selling used copies, or resellers of books } \\
\text { (such as bookstores). For these options they should use Selling on Amazon or Fulfillment by Amazon. }\end{array}$ & $\mathrm{T}$ \\
\hline Advertise with us & Amazon (2007) & External sellers advertisement and selling through Amazon platform. & $\mathrm{R}$ \\
\hline Affiliated Program & Overstock (2000) & $\begin{array}{l}\text { Overstock affiliated program allows you to place links to our products on your web site. By placing these links, visitors to } \\
\text { your site have the opportunity to buy products. If a product is purchased through your web site, a commission, for each sale, is } \\
\text { paid. See: (web.archive.org/web/20000229120514/http://www.overstock.com/alliance.html) }\end{array}$ & $\mathrm{R}$ \\
\hline Affiliated Program & Target (2002) & $\begin{array}{l}\text { Target direct Affiliate Program is a new business-to-business partnership. Join today and start earning commissions on all sales } \\
\text { that you refer. Take advantage of the millions of products offered on our combined site by joining one or both of our affiliate } \\
\text { programs. See: (web.archive.org/web/20030210065618/http://www.target.com/gp/browse.html?node=3008941) }\end{array}$ & $\mathrm{R}$ \\
\hline Alerts Today's Deals & Amazon (2002) & Indicates the deals of the day. & $\mathrm{R}$ \\
\hline Amazon anywhere & Amazon (2001) & Support wireless access to its store. Development of new features for wireless users. & $\mathrm{T}$ \\
\hline Amazon aStore & Amazon (2006) & E-commerce platform/solution & $\mathrm{T}$ \\
\hline Amazon Best Sellers & Amazon (2007) & The most popular items based on sales on Amazon.com. Updated hourly & $\mathrm{T}$ \\
\hline Amazon Connect & Amazon (2006) & Support to Independent Authors (Promotion and Revenues) & $\mathrm{R}$ \\
\hline Amazon Credit Account & Amazon (2001) & Credit Card/Payment Financing & $\mathrm{T}$ \\
\hline $\begin{array}{l}\text { Amazon Currency Con- } \\
\text { verter }\end{array}$ & Amazon (2008) & Currency converter tool for international transactions. & $\mathrm{T}$ \\
\hline Amazon Daily & Amazon (2007) & Blog (permits more direct interaction with consumers) & $\mathrm{S}$ \\
\hline Amazon everywhere & Amazon (2002) & Web Service & $\mathrm{T}$ \\
\hline Amazon FishBowl & Amazon (2006) & Podcasts/short promotional alive videos in related to new products & $\mathrm{R}$ \\
\hline Amazon Fulfillment & Amazon (2008) & $\begin{array}{l}\text { Supply and Distribution Chain Management. Web-to-warehouse high speed picking and sorting system to complete shipping } \\
\text { carrier integration. }\end{array}$ & $\mathrm{T}$ \\
\hline Amazon Podcast & Amazon (2006) & Large media library of podcasts with personalities/celebrities. & $\mathrm{R}$ \\
\hline Amazon Prime & Amazon (2005) & Membership Benefits & $\mathrm{R}$ \\
\hline Amazon Window Shop & Amazon (2008) & Alternative interface for a more interactive/user friendly shopping experience. Drag and drop. iPad version & $\mathrm{R}$ \\
\hline Amazon.com Alerts & Amazon (2000) & E-mail notification & $\mathrm{R}$ \\
\hline Answer Center & eBay (2005) & $\begin{array}{l}\text { FAQs section. Organized by topic and with search option. (See: } \\
\text { hweb.archive.org/web/20050308082606/http://pages.eBay.com/community/answercenter/index.html?ssPageName=comm:f:f) }\end{array}$ & $\mathrm{R}$ \\
\hline App for mobile shopping & Wal-Mart (2010) & iPhone App & $\mathrm{T}$ \\
\hline Apps Center & eBay (2010) & $\begin{array}{l}\text { Enhanced version of eBay Download "Manage and grow your business effortlessly" Apps offered (Customer support, Finance } \\
\text { \& accounting, Inventory, , Listing, Marketing \& merchandising, Research \& reporting, Shipping \& payments and Sourcing) }\end{array}$ & $\mathrm{R}$ \\
\hline Auctions & Overstock (2004) & Customers can bid on products See: (web.archive.org/web/20041012075322/http://auctions.overstock.com/) & $\mathrm{T}$ \\
\hline $\begin{array}{l}\text { Auctions' Management } \\
\text { Tools }\end{array}$ & Overstock (2005) & $\begin{array}{l}\text { Different apps for users are provided to optimize auction process (See: web.archive.org/web/20051208100818/http:// } \\
\text { auctions.overstock.com/cgi-bin/auctions.cgi?PAGE=STATIC\&PAGENUM=102\&caller=m }\end{array}$ & $\mathrm{T}$ \\
\hline Authentication \& Grading & eBay (1999) & Resources to get an expert opinion on your item. & $\mathrm{R}$ \\
\hline Bids \& Auctions & Amazon (1999) & Bids and Auctions & $\mathrm{T}$ \\
\hline Browsing History & Amazon (2006) & History of searches on Amazon. Recently viewed items. & $\mathrm{R}$ \\
\hline Buyer Protection Program & eBay (2003) & Exclusive to registered users. Not possible to retrieve specifications. & $\mathrm{R}$ \\
\hline
\end{tabular}




\begin{tabular}{|c|c|c|c|}
\hline Feature & Website (Date) & Description & Final Code \\
\hline Buying Guides & Overstock (2011) & $\begin{array}{l}\text { Help users to make more informed decisions about your next product purchase. Guides offer detailed research about comput- } \\
\text { ers, duvet covers, plasma TVs, luggage, handbags, digital cameras and many other popular products. }\end{array}$ & $\mathrm{R}$ \\
\hline Club $\mathrm{O}$ & Overstock (2004) & Membership Program (reward and discounts) & $\mathrm{R}$ \\
\hline Community & eBay (1999) & A webpage through which users can access eBay news, press releases, discussions and help boards. & $\mathrm{R}$ \\
\hline Community & Overstock (2008) & $\begin{array}{l}\text { Community Message board, groups, forum. Description on the website: "people like you can interact, entertain and edu- } \\
\text { cate... When we're finished, you'll be able to keep up on current events, speak your mind on your free blog, chat with folks like } \\
\text { you in our forums, and work with others to write the book on the activities that most inspire you. Big changes are coming fast, } \\
\text { so please check back soon." (Forums/Blog/Guides) - Ps. In } 2010 \text { was reformulated and blended social networks services, for } \\
\text { integrating users and spread the word of mouth. }\end{array}$ & $\mathrm{S}$ \\
\hline Connect and Share & Wal-Mart (2002) & Beta version. Services Provided: Classifieds, Customer Reviews, Q\&A Exchange and space for "Your Stories". & $\mathrm{S}$ \\
\hline Connecting to Facebook & Amazon (2010) & $\begin{array}{l}\text { Connect to Friends from your Facebook. "Transport their Facebook friends to Amazon - and can get recommendations from } \\
\text { those friends on what to buy". Tap into your Facebook network to improve your Amazon shopping experience: } \\
\text { Discover Amazon recommendations for movies, music, and more based on your Facebook Favorites and Likes. } \\
\text { See upcoming birthdays and find Amazon Wish Lists for your friends on Facebook more easily. } \\
\text { Get great gift suggestions for your friends based on their Facebook Favorites and Likes. } \\
\text { Explore your friends' Favorites and see who has similar interests. }\end{array}$ & $\mathrm{S}$ \\
\hline Customers' favorites & Overstock (2004) & Items that are best rated in their product category & $\mathrm{S}$ \\
\hline $\begin{array}{l}\text { Customers who bought this } \\
\text { book also bought }\end{array}$ & Amazon (2004) & Suggestion/Product filtering. Purpose: Offer options for Combined Sale & $\mathrm{S}$ \\
\hline $\begin{array}{l}\text { Customers who viewed } \\
\text { this also viewed }\end{array}$ & Overstock (2006) & Indicates associated product visualizations of other customers. Purpose: Offer options for Combined Sale & $\mathrm{S}$ \\
\hline Daily Deals & eBay (2009) & Best deals of the days are displayed. & $\mathrm{T}$ \\
\hline Daily Deals & Target (2009) & Recommendation B-C - Deals of the Day & $\mathrm{T}$ \\
\hline Early Adopters & Amazon (2003) & Monthly email alerts about new releases in technology world. & $\mathrm{R}$ \\
\hline eBay Affiliates & eBay (2000) & $\begin{array}{l}\text { Reward program for website owners (pay per click). See: } \\
\text { web.archive.org/web/20000621103949/http://www.pages.eBay.com/affiliate/index.html }\end{array}$ & $\mathrm{R}$ \\
\hline eBay anything points & eBay (2003) & $\begin{array}{l}\text { Reward System. For users to earn Points from sellers, partners, and special offers, then use your Points to pay for items on } \\
\text { eBay where PayPal is accepted. }\end{array}$ & $\mathrm{R}$ \\
\hline eBay Blogs & eBay (2007) & Users can create their own blogs and share contents and pictures. & $\mathrm{S}$ \\
\hline eBay Cafe & eBay (1999) & $\begin{array}{l}\text { Discussion board to chat with members of the eBay community. In 2007, renamed to chat. General chat rooms and categories- } \\
\text { specific. Announced as "talk with others in a casual setting. See: } \\
\text { web.archive.org/web/20070903022936/http://pages.eBay.com/community/chat/index.html }\end{array}$ & $\mathrm{S}$ \\
\hline eBay community values & eBay (2006) & $\begin{array}{l}\text { Policy and guidelines to participate in eBay community. See: } \\
\text { web.archive.org/web/20060618021752/http://pages.eBay.com/help/newtoeBay/community_overview.html?ssPageName=com } \\
\text { m:f:f:US }\end{array}$ & $\mathrm{R}$ \\
\hline eBay Download & eBay (2004) & Software/apps to help sellers to organize they products/bids (toolbars/turbo lists) & $\mathrm{T}$ \\
\hline eBay express & eBay (2006) & $\begin{array}{l}\text { A new specialty site where customers can buy new, fixed-price goods in a more conventional e-commerce experience. Sellers } \\
\text { have more exposure to top buyers and convenience-oriented buyers at no additional cost. Buyers can shop eBay vast inventory } \\
\text { of brand new, brand name, and hard-to-find products. See: developer.eBay.com/products/roadmap/2006-q2/express/. This } \\
\text { service is not available anymore, see: pages.eBay.com/express/ }\end{array}$ & $\mathrm{T}$ \\
\hline eBay Life & eBay (1999) & $\begin{array}{l}\text { Monthly Newsletter. Announcement "our new online newsletter for the eBay community! In this newsletter, you'll have a great } \\
\text { time reading about your collecting passions, as well as those of other eBay friends. You'll also find out what we are doing to } \\
\text { make your eBay experience a better one." See: web.archive.org/web/19990420062220/http://pages.eBay.com/aw/life- } \\
\text { pageA1.html }\end{array}$ & $\mathrm{R}$ \\
\hline
\end{tabular}




\begin{tabular}{|c|c|c|c|}
\hline Feature & Website (Date) & Description & Final Code \\
\hline eBay Matchups & eBay (2007) & $\begin{array}{l}\text { Pooling social activity, where people create comparison between two products and other members vote. Organizes pools by } \\
\text { most popular and recent ones. See: web.archive.org/web/20070818131133/http://eBaymatchups.com/ }\end{array}$ & $\mathrm{S}$ \\
\hline eBay Mobile & eBay (2008) & eBay.com designed just for small screens. Stay connected to eBay from your mobile phone browser & $\mathrm{T}$ \\
\hline eBay my World & eBay (2007) & $\begin{array}{l}\text { A space for users to: Customize - Pick your favorite features so your My World page looks like you. Personalize - Tell the } \\
\text { world about you: what you sell on eBay, your interests... anything! and Share - Add search tags so you can connect with peo- } \\
\text { ple in the community. See: web.archive.org/web/20070824023109/http://myworld.eBay.com/ }\end{array}$ & S \\
\hline eBay per country & eBay (2000) & $\begin{array}{l}\text { Section in the homepage that directs user to eBays of different countries (Canada, UK, Germany, Japan and Australia). Years } \\
\text { after the number of countries substantially increased. }\end{array}$ & $\mathrm{T}$ \\
\hline eBay Pulse & eBay (2004) & $\begin{array}{l}\text { Welcome to eBay Pulse, a daily snapshot of The World's Online Marketplace } ® \text {. Popular Searches, Largest Stores, Most } \\
\text { watched items. See: web.archive.org/web/20050428081404/http://pulse.eBay.com// }\end{array}$ & $\mathrm{R}$ \\
\hline eBay Safe Harbor & eBay (1999) & $\begin{array}{l}\text { Safe Harbor is eBay's full service customer support and educational resource to ensure safe online trading at eBay and else- } \\
\text { where on the Internet. Safe Harbor consists of several elements designed to keep the eBay community safe. }\end{array}$ & $\mathrm{T}$ \\
\hline eBay Tools & eBay (2002) & $\begin{array}{l}\text { eBay Toolbar, a helpful tool for eBay buyers, keeps track of the items you've bid on and those you're watching. It alerts you } \\
\text { before those auctions end so you can place a bid if you'd like. It could mean the difference between forgetting to bid and win- } \\
\text { ning the auction }\end{array}$ & $\mathrm{R}$ \\
\hline eBay Wiki & eBay (2007) & $\begin{array}{l}\text { Beta version for developers use. They are able to create articles and contribute to others' articles. (See: www.zdnet.com/blog/ } \\
\text { micro-markets/new-eBay-wiki-aims-to-harvest-collective-knowledge-of-the-193-million-eBay-community/117) } \\
\text { (web.archive.org/web/20061027123344/http://www.eBaywiki.com/eBayCommunity?topic=eBayCommunityTopic113) }\end{array}$ & S \\
\hline eBuyer Protection & eBay (2011) & $\begin{array}{l}\text { Coverage/Protection. eBay Buyer Protection covers items purchased on eBay with eligible payment methods that are not re- } \\
\text { ceived or not as described in the listing. Some purchases aren't covered, such as items listed or that should be listed in the } \\
\text { Motors (except for Parts and Accessories) and Real Estate categories, and most prohibited or restricted items. Most Business } \\
\text { and Industrial categories are covered by eBay Buyer Protection. See: } \\
\text { (web.archive.org/web/20110726001110/http://pages.eBay.com/coverage/index.html) }\end{array}$ & $\mathrm{R}$ \\
\hline Email notification & Wal-Mart (2004) & New products deals are submitted to consumers after registration. & $\mathrm{R}$ \\
\hline Email to a friend & Target (2003) & Recommendation of a particular product to a friend that might be interested on that & $\mathrm{S}$ \\
\hline E-mail to a friend & Overstock (2002) & Share an interesting product info/description with a friend that might be interested & $\mathrm{S}$ \\
\hline Escrow & eBay (1999) & Third party that can ensure a safe transfer of your money. Used to prevent fraudulent transactions and protect Buyer and Seller. & $\mathrm{T}$ \\
\hline Evaluation of reviews & Target (2003) & Judgment of reviews (how helpful a review provided by other customers was) & $\mathrm{S}$ \\
\hline Express Checkout & Amazon (2008) & Simplified ordering, checkout and purchase process. & $\mathrm{T}$ \\
\hline Facebook & Overstock (2009) & Add as a friend & $\mathrm{R}$ \\
\hline Facebook & Target (2010) & Follow Target on Facebook & $\mathrm{R}$ \\
\hline Facebook & Wal-Mart (2010) & Follow Wal-Mart on Twitter & $\mathrm{R}$ \\
\hline Favorite saved searches & eBay (2003) & Exclusive to registered users. Not possible to retrieve specifications. & $\mathrm{R}$ \\
\hline Featured Items & eBay (2000) & Lists the last items added to the website & $\mathrm{R}$ \\
\hline Featured items & Wal-Mart (1999) & New products available. & $\mathrm{R}$ \\
\hline FeedBack forum & eBay (1999) & $\begin{array}{l}\text { eBay's system for users to learn more about your trading partner. Every eBay user has a Feedback Profile made up of com- } \\
\text { ments from other traders —an official "reputation." See: web.archive.org/web/19991012065814/http://pages.eBay.com/ ser- } \\
\text { vices/forum/feedback.html }\end{array}$ & $\mathrm{S}$ \\
\hline Friends \& Favorites & Amazon (2002) & $\begin{array}{l}\text { With Friends \& Favorites, users get product information from people they respect. Customers can build their personal network } \\
\text { of Favorite People and follow their opinions and recommendations. }\end{array}$ & $\mathrm{s}$ \\
\hline Gift Alerts & eBay (1999) & Registered users, receive gift alerts, according o preference settings. & $\mathrm{R}$ \\
\hline Gift Central & Amazon (2007) & Gift organizer & $\mathrm{R}$ \\
\hline Gift Options & Wal-Mart (2001) & Gift options/suggestions in some categories are displayed (recommendation B2C) & $\mathrm{R}$ \\
\hline Gift Registry & Wal-Mart (2002) & Search and recommendations of gifts by category, occasion, person, age, price, etc. & $\mathrm{R}$ \\
\hline
\end{tabular}




\begin{tabular}{|c|c|c|c|}
\hline Feature & Website (Date) & Description & Final Code \\
\hline Gift Reminder & Target (2001) & Provides a reminder based on dates provided by the customers (anniversary, birthdates, etc.) & $\mathrm{R}$ \\
\hline $\begin{array}{l}\text { Gift/Wedding and Baby } \\
\text { Registry }\end{array}$ & Target (2000) & Customers can add products & $\mathrm{R}$ \\
\hline Go local, Go global & eBay (2000) & Users can refine products trading according to local preferences. & $\mathrm{R}$ \\
\hline Group Gift & eBay (2011) & $\begin{array}{l}\text { Collective buying functionality. A group gift is composed, friends chip in to the PayPal account and the gift is bought with the } \\
\text { funds collected. See: (http://liveweb.archive.org/http://groupgifts.eBay.com/?_trksid=p5197.m622) }\end{array}$ & $\mathrm{S}$ \\
\hline Guest Services & Target (1999) & $\begin{array}{l}\text { Includes contact with target, order tracking/status, store locations, information about the projects Target supports. See: } \\
\text { (web.archive.org/web/20000229153119/http://target.com/guest_services/index.asp) }\end{array}$ & $\mathrm{R}$ \\
\hline $\begin{array}{l}\text { Guests who bought this } \\
\text { also bought }\end{array}$ & Target (2004) & Product filtering by associated buying/purchasing of other customers. Purpose: Offer options for Combined Sale & $\mathrm{S}$ \\
\hline Guides & eBay (2005) & $\begin{array}{l}\text { Guides enable eBay members to share their expertise on any topic or category. Whatever their interest or expertise, users can } \\
\text { write a guide on it, for example, All About Podcasts \& Podcasting. }\end{array}$ & $\mathrm{S}$ \\
\hline Honor System & Amazon (2001) & $\begin{array}{l}\text { Charitable giving system supported by new technologies. Collective donation and assistance to disaster relief agencies (non- } \\
\text { profit organizations (e.g. Red Cross). }\end{array}$ & $\mathrm{R}$ \\
\hline Hot picks! & eBay (2000) & Recommendation B2C of potential products of interest & $\mathrm{R}$ \\
\hline International Direct & Amazon (2008) & Overseas Shipping service & $\mathrm{T}$ \\
\hline International Websites & Amazon (2001) & Amazon website in other countries & $\mathrm{T}$ \\
\hline iPhone shopping App & Target (2010) & App exclusively for iPhone users to shop on target & $\mathrm{T}$ \\
\hline Learning Center & eBay (2008) & $\begin{array}{l}\text { Tutorials, guides to provide advice on how increasing sales. See: } \\
\text { (web.archive.org/web/20071011013931/http://pages.eBay.com/education/index.html) }\end{array}$ & $\mathrm{R}$ \\
\hline Listmania & Amazon (1999) & This lists includes products customers find interesting and not necessarily purchased from the & $\mathrm{S}$ \\
\hline Live assistance & Overstock (2004) & Support (chat with a representative) & $\mathrm{R}$ \\
\hline Live Auctions & eBay (2003) & $\begin{array}{l}\text { Platform that allowed auction houses to incorporate Internet bidding with their real-life auctions (similar to phone bidding, } \\
\text { only conducted through the Internet). The service was closed in 2009. (See: blog.auctionbytes.com/cgi- } \\
\text { bin/blog/blog.pl?/pl/2009/1/1230832809.html) }\end{array}$ & $\mathrm{T}$ \\
\hline Map Search & Target (2000) & Search for weekly ads by location (in the U.S territory) & $\mathrm{R}$ \\
\hline May we suggest & Overstock (2005) & Pop-up feature based on B2C recommendation; indicates potential interesting products when a particular product is selected. & $\mathrm{R}$ \\
\hline Mentoring Center & eBay (2007) & $\begin{array}{l}\text { Join a Mentoring Group and receive help from another eBay member on how to use eBay. Meet other new members and learn } \\
\text { together. See: (web.archive.org/web/20071009122525/http://groups.eBay.com/index.jspa?categoryID=100000486\&start=0) }\end{array}$ & $\mathrm{S}$ \\
\hline Mobile Access & Amazon (2002) & Mobile Access & $\mathrm{T}$ \\
\hline Mobile $\mathrm{O}$ & Overstock (2010) & Website version for smartphones and apps for shopping experience & $\mathrm{T}$ \\
\hline Mobile Text Alert & Target (2010) & Receive text messages from Target in your mobile & $\mathrm{R}$ \\
\hline $\begin{array}{l}\text { Mobile version for all } \\
\text { smartphones }\end{array}$ & Wal-Mart (2011) & Mobile Website Version & $\mathrm{T}$ \\
\hline Mobile Website & Target (2010) & Mobile Website Version & $\mathrm{T}$ \\
\hline More Recommendations & Wal-Mart (2001) & Link to additional recommendations (B2C) & $\mathrm{R}$ \\
\hline Most frequently searched & eBay (2002) & Rank of the top ten items searched by other users & $\mathrm{S}$ \\
\hline $\begin{array}{l}\text { Most-wanted-item notifica- } \\
\text { tions }\end{array}$ & eBay (2003) & Exclusive to registered users. Not possible to retrieve specifications. & $\mathrm{R}$ \\
\hline Moves and Shakers & Amazon (2001) & Sales ranks of items organized by categories are hourly updated. Kind of "stock market" dynamic and display. & $\mathrm{R}$ \\
\hline My eBay & eBay (2000) & $\begin{array}{l}\text { Members Profile according to preference settings. See: } \\
\text { web.archive.org/web/20000302064732/http://pages.eBay.com/services/myeBay/myeBay.html }\end{array}$ & $\mathrm{R}$ \\
\hline My info & Target (1999) & In the same year replaced by "My Target", where customers are able to manage their transactions and profile information. & $\mathrm{R}$ \\
\hline Neighborhoods & eBay (2007) & $\begin{array}{l}\text { Announced as: places for people like you who want to connect via their shared passions for products and topics. You can jump } \\
\text { right in, or just come by and watch - it’s up to you. People Profiles and activities available. Sort of internal social network. See: } \\
\text { (web.archive.org/web/20071010065156/http://neighborhoods.eBay.com/). Service was discontinued as of April } 302012\end{array}$ & $\mathrm{~S}$ \\
\hline
\end{tabular}




\begin{tabular}{|c|c|c|c|}
\hline Feature & Website (Date) & Description & Final Code \\
\hline O mail & Overstock (2002) & Email notification. Sign up for receiving deals & $\mathrm{R}$ \\
\hline Obiz & Overstock (2009) & $\begin{array}{l}\text { A website where businesses and customers can buy bulk merchandise. O.BIZ is designed to give small businesses and custom- } \\
\text { ers the opportunity to buy large quantities at deep discounts. See: (web.archive.org/web/20091226041251/http://www.o.biz/?) }\end{array}$ & $\mathrm{S}$ \\
\hline O-minders & Overstock (2006) & Free reminder of special dates service & $\mathrm{R}$ \\
\hline OMUSE & Overstock (2007) & $\begin{array}{l}\text { Omuse is a place for people with similar interests to find each other and team up to "write the book" on the activities they love. } \\
\text { We expect the result of that collaboration to be a vast collection of constantly evolving "guides" intended to teach, edify and, } \\
\text { most of all, inspire others. (web.archive.org/web/20070716173130/http://omuse.overstock.com/wiki/Main_Pag) }\end{array}$ & $\mathrm{S}$ \\
\hline O-text & Overstock (2009) & Mobile Service to get messages about new products and deals & $\mathrm{R}$ \\
\hline $\begin{array}{l}\text { Personalized recommenda- } \\
\text { tion }\end{array}$ & Target (2002) & $\begin{array}{l}\text { B2C. Some products are suggested accordingly to customer profile (not sure how the data is collected. Through previous } \\
\text { shopping activities, clicks/navigation?) }\end{array}$ & $\mathrm{R}$ \\
\hline Personalized shopping & eBay (2003) & \begin{tabular}{|l} 
Exclusive to registered users. Not possible to retrieve specifications. \\
\end{tabular} & $\mathrm{R}$ \\
\hline Pools & Overstock (2004) & \begin{tabular}{|l|l} 
To evaluate how helpful descriptions and information provided about an item was \\
\end{tabular} & $\mathrm{S}$ \\
\hline Price Comparison & Overstock (2004) & Compares prices of products with other retailers (e.g., Amazon) & $\mathrm{R}$ \\
\hline Products' videos & Overstock (2011) & Videos related to the products, showing use, but not generated by consumers. Purpose to enhance product visualization. & $\mathrm{R}$ \\
\hline Purchase Circles & Amazon (1999) & $\begin{array}{l}\text { Helps shoppers discover thousands of favorite products by customer communities. Unique Best Sellers List (relatives, organi- } \\
\text { zations, location etc.). Purpose: Assist with personal buying decisions (more informed purchases); and to help select gift items } \\
\text { for others based on the Purchase Circles to which they belong. }\end{array}$ & S \\
\hline Rating & Wal-Mart (2008) & Stars rating for products & $\mathrm{S}$ \\
\hline Ratings & Target (2003) & Customers rate products & $\mathrm{S}$ \\
\hline $\begin{array}{l}\text { Real Opinions, Smart } \\
\text { Shopping }\end{array}$ & Wal-Mart (2008) & $\begin{array}{l}\text { Announcement (we are listening, Add your voice now) Real opinions/Smart Shopping! - instructions of how to rate and re- } \\
\text { view products. }\end{array}$ & $\mathrm{S}$ \\
\hline Recent Searches & Target (2002) & Viewed products by categories & $\mathrm{R}$ \\
\hline Recent viewed items & Wal-Mart (2010) & Track history of items searched and previously viewed & $\mathrm{R}$ \\
\hline Recent visited items & Overstock (2006) & \begin{tabular}{|l} 
Track navigation history of items searched and previously viewed by the customer \\
\end{tabular} & $\mathrm{R}$ \\
\hline Related Items & Wal-Mart (1999) & Products related to the search are displayed (recommendation B2C) & $\mathrm{R}$ \\
\hline Remind me List & Wal-Mart (2011) & Reminder of special dates (anniversary, birthday, Xmas, etc.) & $\mathrm{R}$ \\
\hline Review feedback & eBay (2003) & \begin{tabular}{|l} 
Feedback ratings are based on a user's past transactions and help you learn about the seller you're dealing with. \\
\end{tabular} & $\mathrm{S}$ \\
\hline Reviews & Overstock (2002) & \begin{tabular}{|l|} 
Read/Write Customer Reviews, no rating included. \\
\end{tabular} & $\mathrm{S}$ \\
\hline Reviews & Target (2003) & Customers provide their opinion about the product & $\mathrm{S}$ \\
\hline Reviews \& Ratings & eBay (2005) & 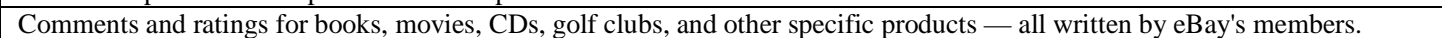 & $\mathrm{S}$ \\
\hline Reviews' evaluation & Overstock (2010) & Judgment of reviews (helpful, not helpful) & $\mathrm{S}$ \\
\hline RSS feeds & Overstock (2008) & Track website updates without necessarily visiting it & $\mathrm{R}$ \\
\hline RSS feeds & Wal-Mart (2007) & \begin{tabular}{|l|l} 
Track website updates without necessarily visiting it \\
\end{tabular} & $\mathrm{R}$ \\
\hline Sales Meters & Amazon (2008) & \begin{tabular}{|l|} 
Pooling combined with website statistics. \\
\end{tabular} & $\mathrm{T}$ \\
\hline Saved searches & eBay (2009) & Users can track search past history, bids they won, etc. integrated to My eBay. & $\mathrm{R}$ \\
\hline $\begin{array}{l}\text { Search within ac- } \\
\text { tions/users/bids by region }\end{array}$ & eBay (1999) & Earlier version of Smart Search which was released in 2000, where users could filter auctions and biddings activities. & $\mathrm{T}$ \\
\hline Sell your stuff & Amazon (2002) & People or small business feature to sell products through Amazon platform. & $\mathrm{T}$ \\
\hline Seller Tools & eBay (2003) & $\begin{array}{l}\text { Whether you list ten, a hundred, a thousand or more items, Seller Tools will help make you much more efficient at listing and } \\
\text { managing your sales. Turbo Lister, Selling Manager and Selling Manager Pro have been designed to fit your needs and max- } \\
\text { imize your sales. See: (web.archive.org/web/20031203033943/http://pages.eBay.com/sell/tools.html). Currently named: Seller } \\
\text { Tools \& eBay Stores }\end{array}$ & $\mathrm{T}$ \\
\hline $\begin{array}{l}\text { Share this auction with a } \\
\text { friend }\end{array}$ & eBay (1999) & Way to spread the word to potential buyers and people interest in a specific product. & $\mathrm{s}$ \\
\hline $\begin{array}{l}\text { Shop the } \mathrm{O} \text { on the go, daily } \\
\text { deals }\end{array}$ & Overstock (2004) & $\begin{array}{l}\text { Overstock deals sent directly to the cell phone (restricted models) - See: } \\
\text { (web.archive.org/web/20041013074052/http://www.overstock.com/cgi- }\end{array}$ & $\mathrm{R}$ \\
\hline
\end{tabular}




\begin{tabular}{|c|c|c|c|}
\hline & & bin/d2.cgi?SEC_IID=4520\&PAGE=STATICPAGE\&PAGE_ID=1007) & \\
\hline Feature & Website (Date) & Description & Final Code \\
\hline Smart Search & eBay (2000) & Reformulated version of previous search with additional keywords, price range, geographical settings, etc. & $\mathrm{T}$ \\
\hline $\begin{array}{l}\text { Special Occasions Re- } \\
\text { minders }\end{array}$ & Amazon (1999) & Reminder system for special dates & $\mathrm{R}$ \\
\hline Suggestion Box & eBay (1999) & C2B communication channel for comments, complaints and suggestions. & $\mathrm{R}$ \\
\hline Top items of the year & Target (2003) & Most sold items in a particular year are displayed (B2C) & $\mathrm{R}$ \\
\hline Top rated items & Wal-Mart (2008) & Indication of top rated items in each category & $\mathrm{S}$ \\
\hline Top Searches & Overstock (2006) & Most searched items (general) - other customers & $\mathrm{R}$ \\
\hline Top sellers & Amazon (2000) & Ranking of top sales in a specific category & $\mathrm{R}$ \\
\hline Top Sellers & Overstock (1999) & Indication of top seller products according to the website (B2C) & $\mathrm{R}$ \\
\hline Top Selling items & Overstock (2010) & Indicates associated product visualizations of other customers & $\mathrm{R}$ \\
\hline Top Sells & Wal-Mart (2004) & Most sold items in a particular category are displayed (B2C) & $\mathrm{R}$ \\
\hline Tweets about overstock & Overstock (2010) & Tweets about Overstock are displayed at in the webpage & $\mathrm{S}$ \\
\hline Twitter & Overstock (2009) & Follow Overstock Twitter & $\mathrm{R}$ \\
\hline Twitter & Target (2010) & Follow Target on Twitter & $\mathrm{R}$ \\
\hline Twitter & Wal-Mart (2010) & Add as a friend & $\mathrm{R}$ \\
\hline $\begin{array}{l}\text { Universal Currency Con- } \\
\text { verter }\end{array}$ & eBay (2003) & $\begin{array}{l}\text { This is a version of the XE.com Universal Currency Converter }{ }^{\circledR} \text {, the world's most popular currency tool. Users can perform } \\
\text { interactive foreign exchange rate calculations, using live, up-to-the-minute currency rates. }\end{array}$ & $\mathrm{T}$ \\
\hline Value of the day & Wal-Mart (2011) & Special deals & $\mathrm{R}$ \\
\hline Verified eBay User & eBay (1999) & Indication that a user's personal information has been verified. & $\mathrm{R}$ \\
\hline Verified eBay User & eBay (2011) & $\begin{array}{l}\text { Updated daily. List of items. Not sure if does items are based on searches or purchases. See: } \\
\text { web.archive.org/web/20110401181255/http://www.eBay.com/ }\end{array}$ & $\mathrm{R}$ \\
\hline Video Reviews & Amazon (2007) & Visual comments and opinions about products sold on the website. & $\mathrm{S}$ \\
\hline Wal-Mart News & Wal-Mart (2002) & Press releases, news about store openings, etc. & $\mathrm{R}$ \\
\hline Wal-Mart Wire Email & Wal-Mart (2005) & Email of sales, clearances, roll-back items opportunities. & $\mathrm{R}$ \\
\hline Website personalization & Amazon (2002) & Personalization of the position of items in the website & $\mathrm{R}$ \\
\hline $\begin{array}{l}\text { What Other Customers Are } \\
\text { Looking At Right Now }\end{array}$ & Amazon (2007) & Recommendation System & $\mathrm{S}$ \\
\hline Where is my stuff? & Amazon (2000) & Order tracking & $\mathrm{T}$ \\
\hline Wish Lists & Target (2001) & Customers can add products they plan or want to purchase & $\mathrm{R}$ \\
\hline Wish Lists & Wal-Mart (2005) & customers can add products they want to buy & $\mathrm{R}$ \\
\hline Word Clouds & eBay (2007) & $\begin{array}{l}\text { In eBay My World, word based on the tags extracted from the content of the website (not sure from which part) is displayed. } \\
\text { See: (web.archive.org/web/20070824023109/htp://myworld.eBay.com/), one year later in the homepage to indicated "what is } \\
\text { in demand?", see: (web.archive.org/web/20090705135753/http://www.eBay.com/) }\end{array}$ & $\mathrm{S}$ \\
\hline You might be interested in & Amazon (2004) & Recommendation System & $\mathrm{R}$ \\
\hline Your lists manager & Amazon (2007) & Lists' organizer & $\mathrm{R}$ \\
\hline Your media Library & Amazon (2006) & Media Organizer & $\mathrm{R}$ \\
\hline Your store & Amazon (2002) & Account and personal information manager & $\mathrm{R}$ \\
\hline YouTube & Overstock (2010) & Related Videos. Watch videos produced by Overstock (www.youtube.com/user/OverstockOnline) & $\mathrm{R}$ \\
\hline YouTube & Target (2010) & Related Videos. Watch videos produced by Target. & $\mathrm{R}$ \\
\hline Zshops & Amazon (1999) & $\begin{array}{l}\text { Retails Merchants or Individuals can use Amazon platform and have access to Amazon's customer's platform for business } \\
\text { transactions. }\end{array}$ & $\mathrm{T}$ \\
\hline
\end{tabular}




\section{Appendix B - Amazon Timeline}

\section{Amazon's Technical Features}

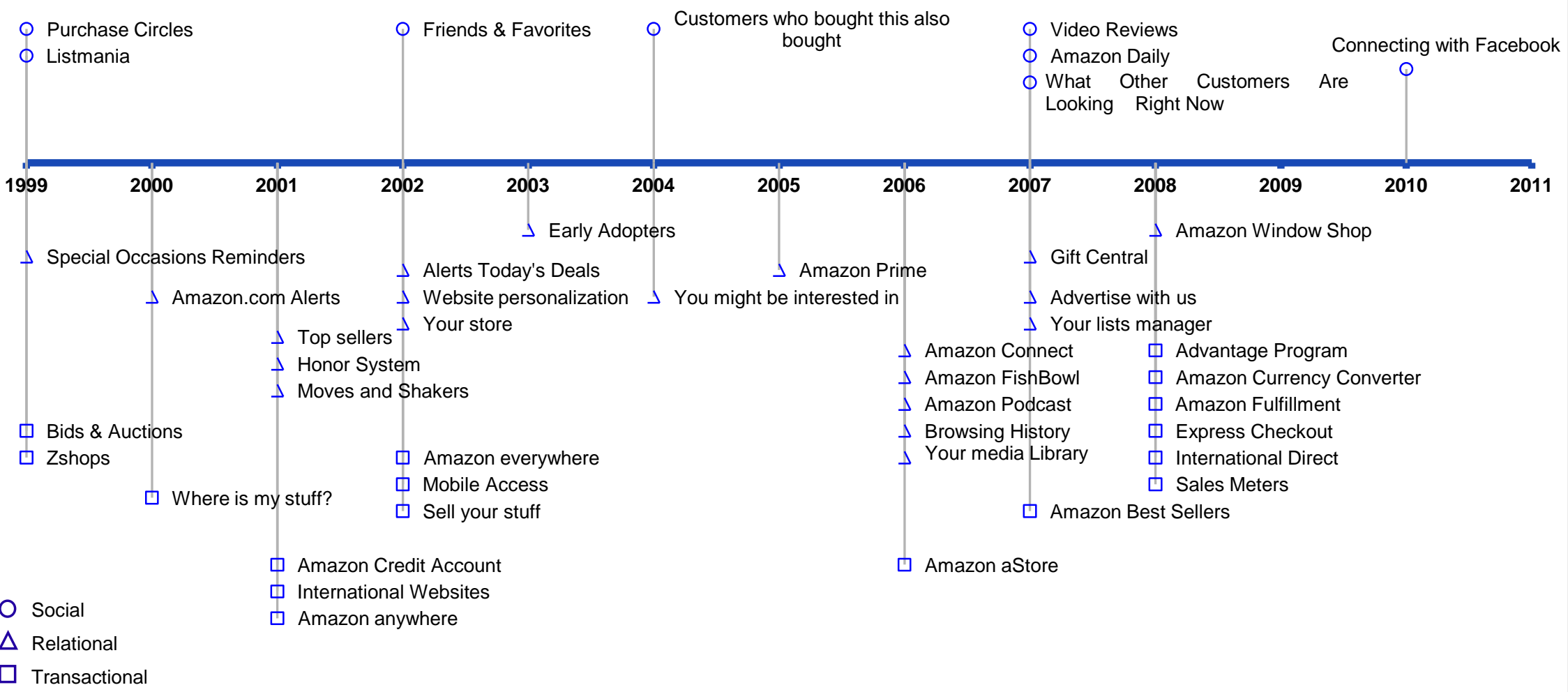




\section{Appendix C - eBay Timeline}

\section{eBay's Technical Features}

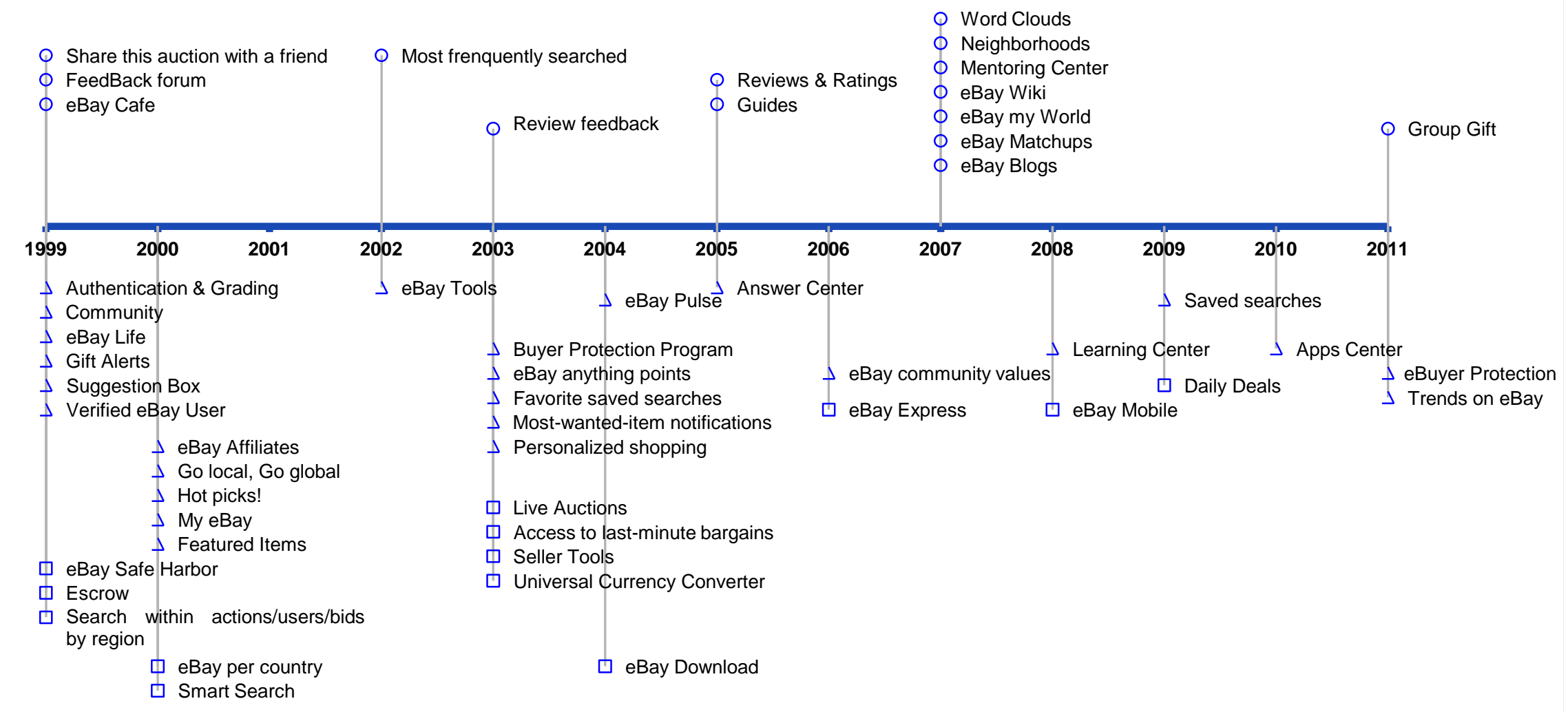

O Social

$\triangle$ Relational

$\square$ Transactional 


\section{Appendix C - Overstock Timeline}

\section{Overstock's Technical Features}

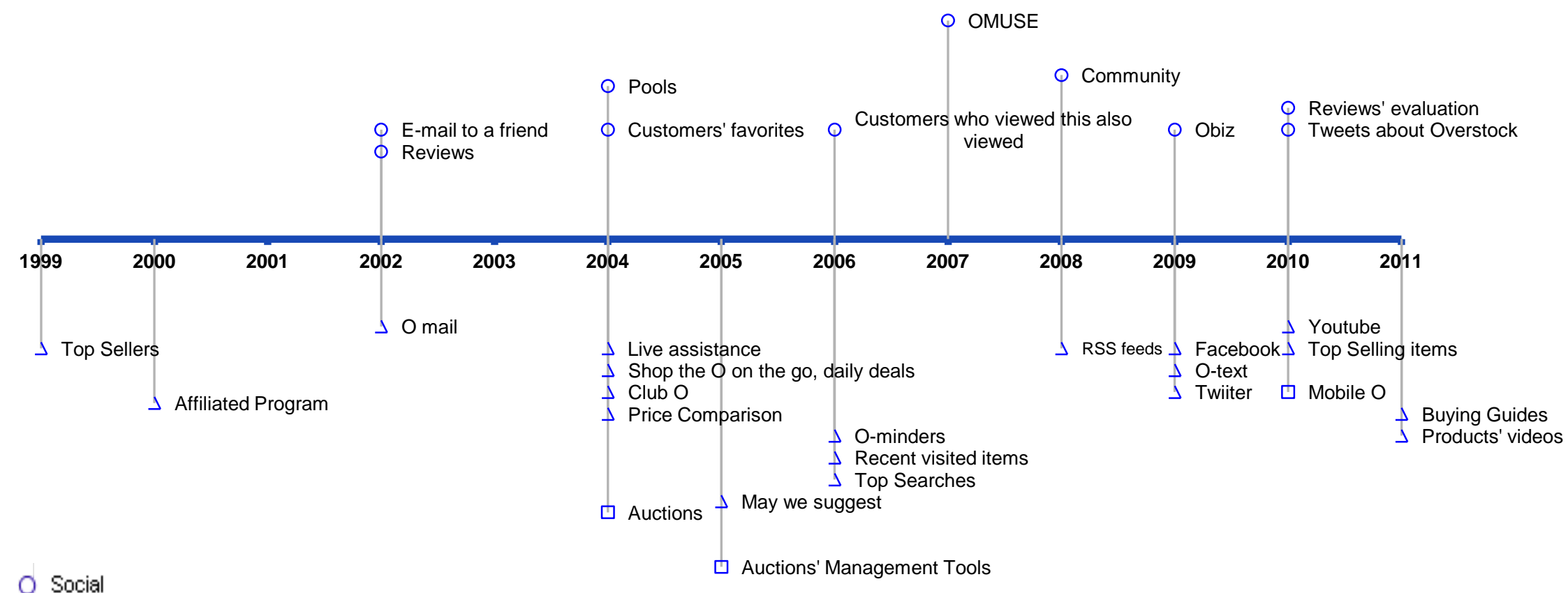

\section{$\Delta$ Relational}

$\square$ Transactional 


\section{Appendix D - Target Timeline}

\section{Target's Technical Features}

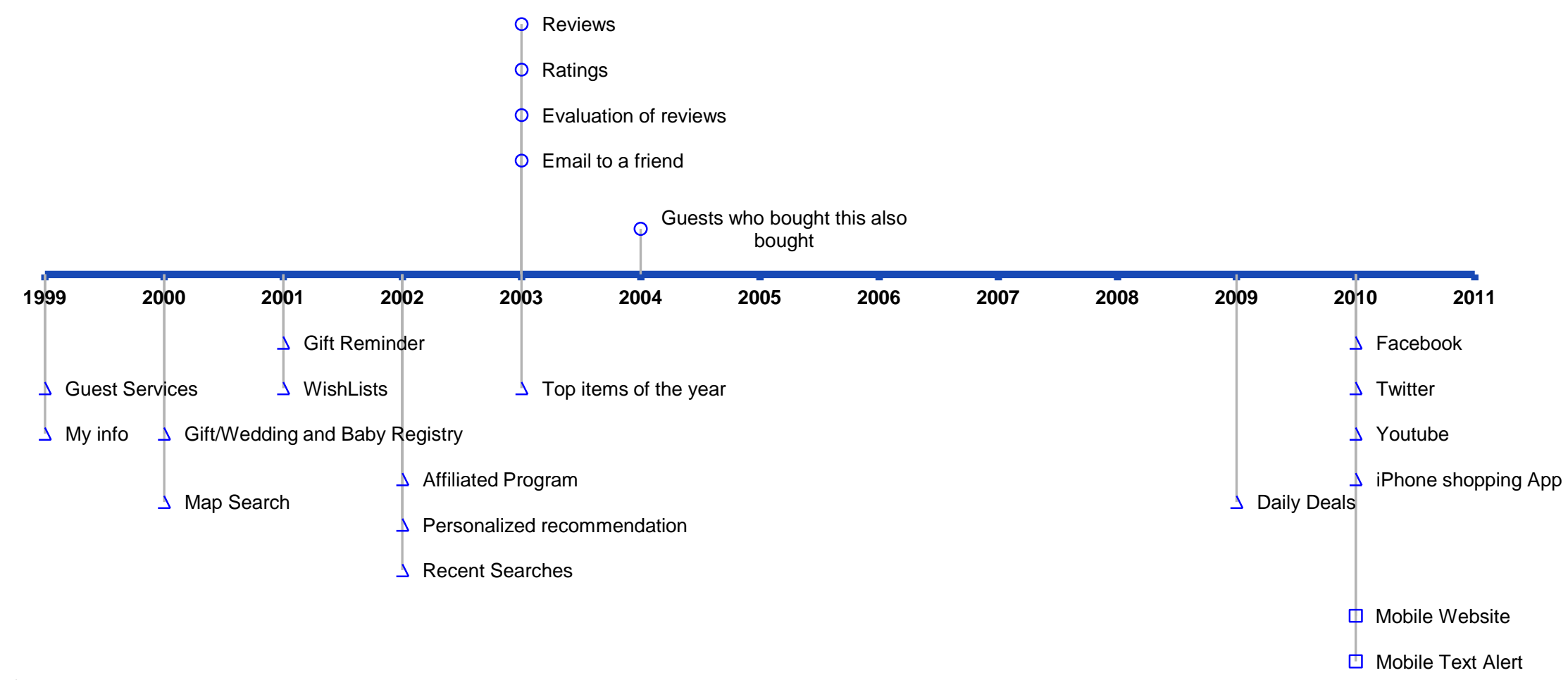
O Social
$\Delta$ Relational
$\square$ Transactional 


\section{Appendix E - Wal-Mart Timeline}

\section{Wal-Mart 's Technical Features}

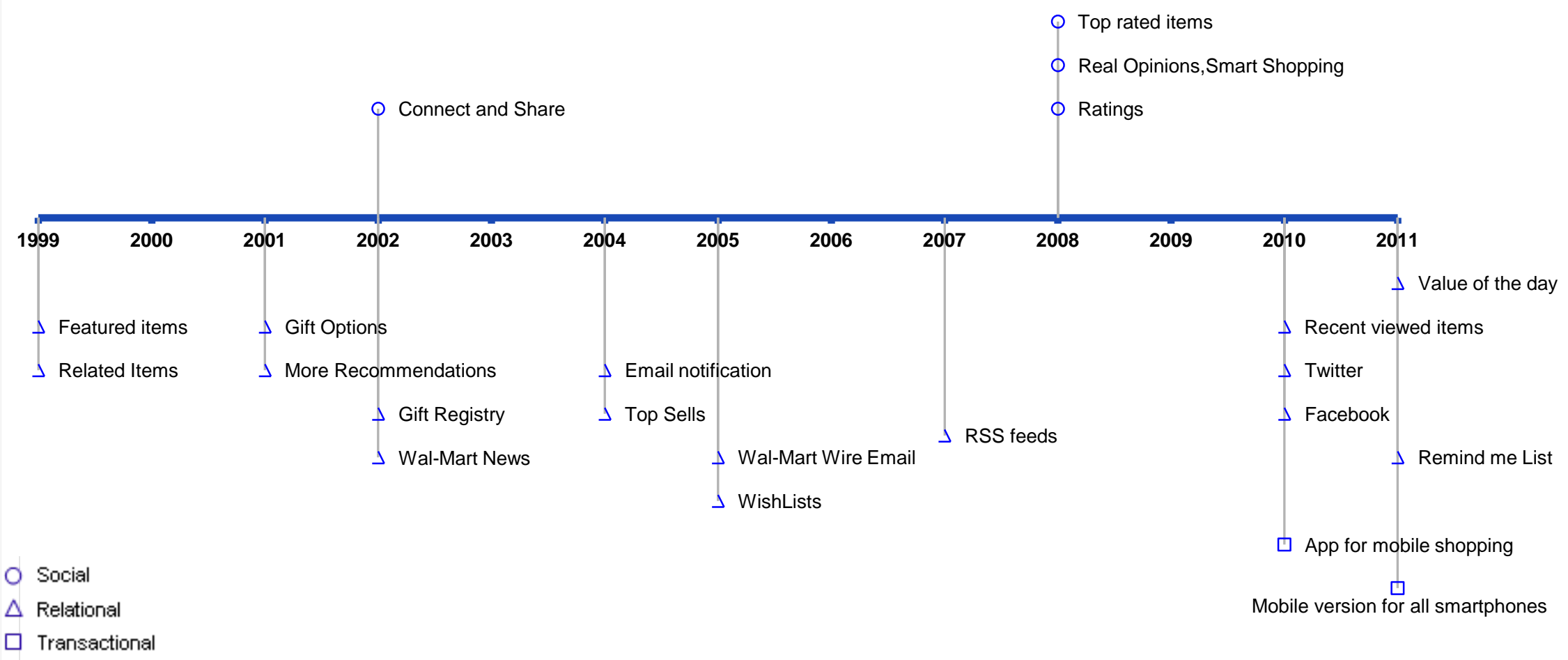

